\title{
Northern Shrimp (Pandalus borealis) on Flemish Cap (NAFO Division 3M) - Oceanography, Fishery and Biology
}

\author{
D. G. Parsons, E. B. Colbourne, G. R. Lilly and D. W. Kulka \\ Science Branch, Department of Fisheries and Oceans \\ P. O. Box 5667 St. John's, Newfoundland, Canada A1C 5X1
}

\begin{abstract}
The purpose of this paper is to consolidate information presented to the Scientific Council of NAFO during 1993-95 on northern shrimp (Pandalus borealis) on Flemish Cap. Also included are sections on oceanography of the area, general biology of the species and by-catch of fish in the commercial fishery for shrimp.

Oceanographic data describe the habitat in relation to bathymetry, temperature, salinity and circulation. Shrimp distribution, determined from research surveys, commercial fishery data and stomach contents of cod (Gadus morhua), occurred within depths of 200$600 \mathrm{~m}$ where temperatures and salinities were approximately $4.0^{\circ} \mathrm{C}$ and $34.0 \mathrm{PSU}$, respectively. An anticyclonic gyre over the centre of the Cap dominated the circulation, providing a mechanism for the retention of shrimp larvae in the area. The bottom trawl fishery for shrimp, which began in 1993, increased rapidly through the participation of vessels from several nations. Catches decreased from about 28000 tons in 1993 to 24000 in 1994 but increased to 33000 in 1995 . Fishery regulations initially dealt with limiting by-catch, primarily redfish (Sebastes sp.), and concerns about discard mortality led to mandatory use of sorting grates in shrimp trawls in 1994. A substantial decline in redfish by-catches in 1995 was coincident with a decrease in the bar spacings of sorting grates and with an increase in individual size and decrease in numbers of a strong redfish year-class.

Catch-effort data from the fishery (1993-95) and research trawl surveys (1988-95) provided indices of biomass which showed a large increase between 1990 and 1992 and a decline, thereafter. Biological sampling for length, sex and maturity from both sources were used to determine age and growth. Shrimp on the Flemish Cap show life history characteristics similar to warm water populations at early life stages and to cold water populations later in life, consistent with influences of both the Gulf Stream and Labrador Current in the Flemish Cap area. Several species of finfish in the Flemish Cap community are predators and/or competitors of shrimp but relationships between the abundance of shrimp and the abundance of any other species have not been investigated.
\end{abstract}

Key words: biology, by-catch, Flemish Cap, northern shirmp, oceanography

\section{Introduction}

Northern shrimp (Pandalus borealis Krøyer, 1838) has long been considered the primary coldwater shrimp resource in the Northwest Atlantic (Longhurst, 1970). Statistics from the Northwest Atlantic Fisheries Organization (NAFO) Convention Area show that recent annual catches of these shrimp have been the highest reported for all marine crustacea (NAFO, 1995a).

The occurrence of northern shrimp on Flemish Cap (NAFO Division 3M) (Fig. 1a) has been known for many years. Squires (1970) reported the spe- cies "in considerable numbers ... near the Flemish Cap", thereby contributing to the knowledge of its widespread distribution throughout the Northwest Atlantic (see below and Allen, 1959). Detailed information on the distribution and biology of shrimp in this area was lacking until 1988 when a European Union (EU-Spain) research survey caught them frequently in a lined, groundfish trawl (Vazquez, MS 1989). Similar surveys, conducted annually, have provided a valuable time series of information on recent changes in distribution, relative biomass and demographic structure of the shrimp (Sainza, MS 1995). Additional data on distribution and biology have been obtained from 

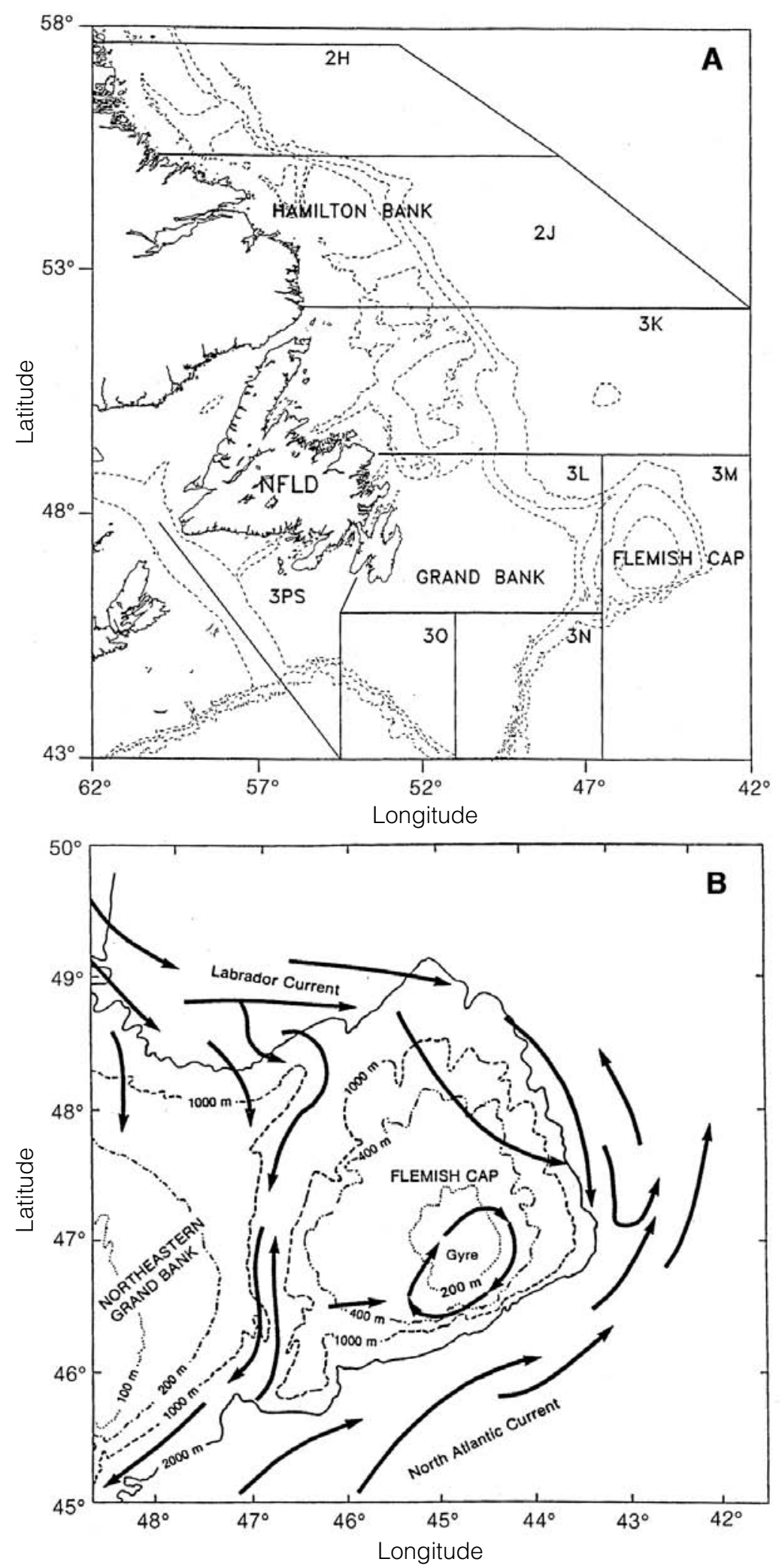

Fig. 1. (A) Location map of the Flemish Cap (bathymetry lines are 300, 1000 and $2000 \mathrm{~m}$ ) and (B) major circulation features (adapted from Anderson, 1984). 
commercial fishing vessels of several nations since the spring of 1993. In this paper, we review and consolidate information relevant to northern shrimp on Flemish Cap from published literature and reports presented at NAFO Scientific Council meetings in 1993, 1994 and 1995. New analyses of the spatial distribution of the fishery and finfish bycatch also are provided.

\section{The Physical Environment of Flemish Cap}

The Flemish Cap is a large, relatively deep bank located east of the Grand Bank of Newfoundland at about $47^{\circ} \mathrm{N}, 45^{\circ} \mathrm{W}$ (Fig. 1A). Minimum water depth is about $150 \mathrm{~m}$. The diameter of the bank at the 500 $\mathrm{m}$ isobath is about $200 \mathrm{~km}$ for a total area of approximately $3.0 \times 10^{4} \mathrm{~km}^{2}$. To the west, the Cap is separated from Grand Bank by the Flemish Pass with water depths of $1000-1100 \mathrm{~m}$. At the $2000 \mathrm{~m}$ isobath the bank appears as an eastward extension of the Newfoundland Continental Shelf Slope.

The water mass over Flemish Cap is a mixture of Labrador Current water and North Atlantic Current water, producing water temperatures that are higher than those over the adjacent Grand Bank within similar depth ranges. For example, at depths of 100-150 m bottom temperatures over the Grand Bank are generally less than $0.0^{\circ} \mathrm{C}$ compared to about 3.0 to $4.0^{\circ} \mathrm{C}$ over the Flemish Cap (Colbourne and Senciall, 1996). Flemish Cap is relatively ice free. The ice edge encroaches briefly during February and March of severe ice years.

\section{Circulation}

Two major current systems dominate the circulation around the Flemish Cap. The offshore branch of the Labrador Current transports cold, low salinity water to the south through the Flemish Pass and to the east and southeast around the northern and eastern slopes of the bank. The North Atlantic Current transports warmer, high salinity water to the northeast along the southeast slope of Grand Bank and the Flemish Cap (Fig. 1B). The circulation over the centre of the Cap is dominated by a topographically induced anticyclonic (clockwise) gyre (Kudlo et al., 1984; Ross, 1981). The stability of this circulation pattern is strongly influenced by atmospheric forcing at weather band frequencies. Kudlo et al. (1984) have shown that there are frequent cross-shelf meander type flows, the frequency of which is greatest during the winter months when the mean wind speed is greatest. Variations in the Labrador current, the Gulf Stream and the Northwest Atlantic Current likely play important roles in the circulation in the area.

A survey in July 1993, using acoustic Doppler current profilers (ADCPs), has provided a more detailed view of the currents (Colbourne, MS 1993). In the Flemish Pass, the offshore edge of the Labrador current, up to $200 \mathrm{~m}$ deep, flowed at about $15 \mathrm{~cm} / \mathrm{s}$ in a general southerly along-shelf direction (Fig. 2). Over the Flemish Cap itself the circulation was predominately anticyclonic with northward currents of $5-15 \mathrm{~cm} / \mathrm{s}$ over the western portion of the bank and southward currents of $5-15 \mathrm{~cm} / \mathrm{s}$ over the eastern portion. These data suggest a recirculation time of roughly 10 weeks along the $500 \mathrm{~m}$ isobath (gyre width of approximately $200 \mathrm{~km}$ ) at an average current speed of about $10 \mathrm{~cm} / \mathrm{s}$. Further up on the bank, within the $200 \mathrm{~m}$ isobath, recirculation times were in the order of 50 days at $10 \mathrm{~cm} / \mathrm{s}$.

Recirculation times calculated from synoptic observations are not necessarily equivalent to residence times of the water mass over the Cap. Available data suggest that residence times are significantly less than recirculation times. For example, Loder et al. (1988) used drifter tracks to calculate mean recirculation times of 67-78 days along the $400 \mathrm{~m}$ isobath with residence times of about 32 days. This indicates that variability in the meandering cross-bank flow may be the most significant circulation feature from a biological perspective. As postulated by Kudlo and Borovkov (1977) and by Kudlo and Boytsov (1979), the stability of the circulation patterns around the Flemish Cap may influence the retention of ichthyoplankton on the bank and is probably a factor in determining the year-class strength of various species such as cod, redfish and shrimp. This hypothesis has not been tested (Lilly 1987).

\section{Temperature and Salinity}

Seasonal changes in temperature and salinity over central Flemish Cap along the $47^{\circ} \mathrm{N}$ line were calculated by Colbourne and Senciall (1996) from data available for 1931 to 1995 (Fig. 3). The water column is nearly isothermal at about $4.0^{\circ} \mathrm{C}$ from January until April and remains at about $4.0^{\circ} \mathrm{C}$ throughout the remainder of the year at depths below approximately $100 \mathrm{~m}$ (Fig. 3A). Seasonal warming of the upper layer commences by early- 


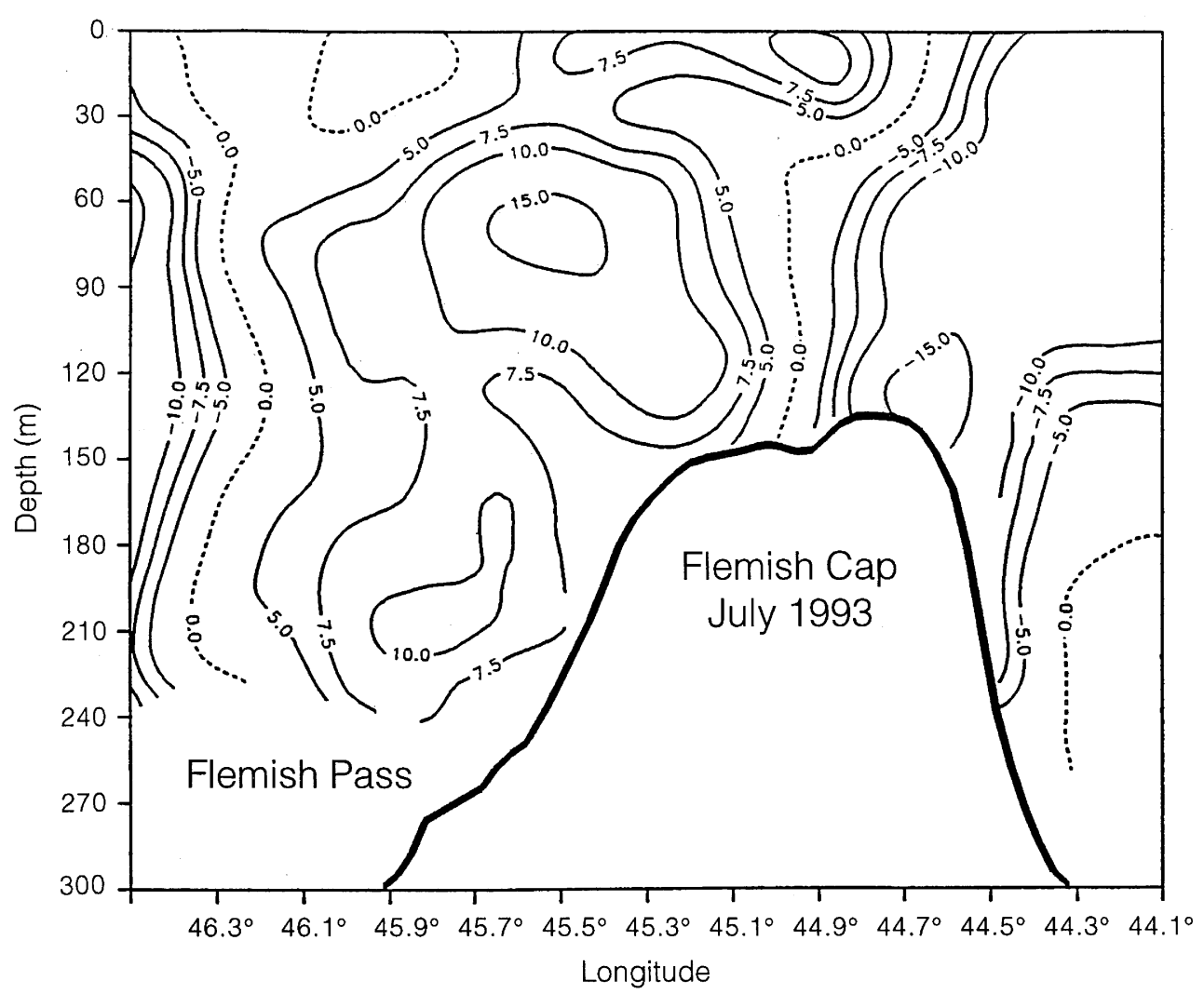

Fig. 2. Vertical cross-section of the north-south current field $(\mathrm{cm} / \mathrm{s})$ over the Flemish Cap along $47^{\circ} \mathrm{N}$ during July 1993. Negative currents are southward, positive currents northward (from Colbourne, MS 1993).

May and progresses at a rate of about $0.1^{\circ} \mathrm{C}$ per day until late-August or early-September when it reaches a maximum of between 12.0 and $13.0^{\circ} \mathrm{C}$. The seasonally heated upper layer reaches a maximum depth of about 80 to $90 \mathrm{~m}$ by late-November by which time the surface layer is cooling. In January, salinity ranges from about 33.5 practical salinity units (PSU) in the upper water column to about 34.25 PSU near the bottom (Fig. 3B). Conditions tend to be isohaline near 34.0 to $34.25 \mathrm{PSU}$ from March until June after which the upper layers experience a gradual freshening, reaching a minimum of 33.5 PSU by mid-July. At depths greater than $90 \mathrm{~m}$, salinities remain at about 34.0 to 34.25 PSU throughout the year.

The vertical distribution of the July average temperature and salinity over the Flemish Cap along the standard $47^{\circ} \mathrm{N}$ transect based on all available historical data from 1961 to 1990 (Colbourne, MS 1996) are shown in Fig. 4. The average temperature ranged from about 10 to $11^{\circ} \mathrm{C}$ near the surface to $4.0^{\circ} \mathrm{C}$ at $50 \mathrm{~m}$ depth. In deeper water $(50 \mathrm{~m}$ to the bottom), the temperature ranged from 2.0 to $3.5^{\circ} \mathrm{C}$ in the Flemish Pass area, in the offshore branch of the Labrador Current, and from 3.5 to $5.0^{\circ} \mathrm{C}$ east of the bank where the influence of the Gulf Stream was evident (Fig. 4A). The corresponding July average salinities generally ranged from 33.5 PSU near the surface to 34.75 PSU near the bottom over the Flemish Cap in water depths of about $300 \mathrm{~m}$. In water depths greater than $300 \mathrm{~m}$ salinities were generally greater than 34.75 PSU (Fig. 4B).

Temperature and salinity anomalies at standard depths over the period 1970-94 were constructed by subtracting a least squares fit to the seasonal cycle from each observation (Colbourne, MS 1993). This time series of residuals was then low pass filtered to highlight interannual variations and to suppress the high frequency variations shorter than a season. The time series of temperature anomalies at depths down to at least $100 \mathrm{~m}$ (Fig. 5A) were characterized by 3 major cold periods: most of the 1970 s, the mid-1980s and the late-1980s to early1990s. The cold period, beginning around 1971, continued until 1977. Temperature anomalies 

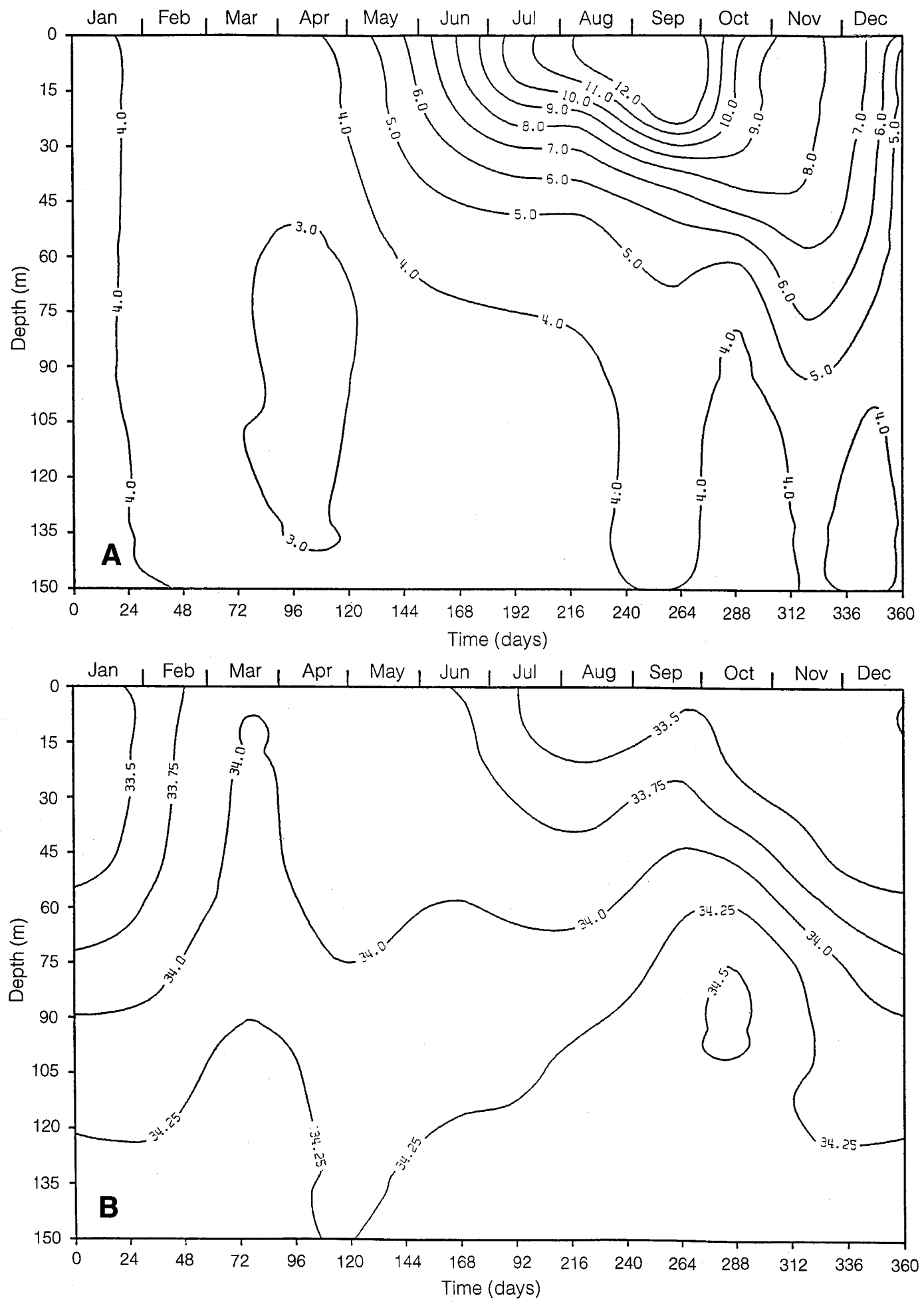

Fig. 3. Time series of the monthly mean (A) temperature and (B) salinity over the central Flemish Cap along $47^{\circ} \mathrm{N}$ based on all available historical data from 1931-95 (Colbourne and Senciall, 1996).

reached values of $1.5^{\circ} \mathrm{C}$ below normal over the upper water column in 1974. From 1978 to 1984, the temperature anomalies showed a high degree of variability in the upper water column with a tendency towards positive anomalies. By 1985, intense negative temperature anomalies had returned with 

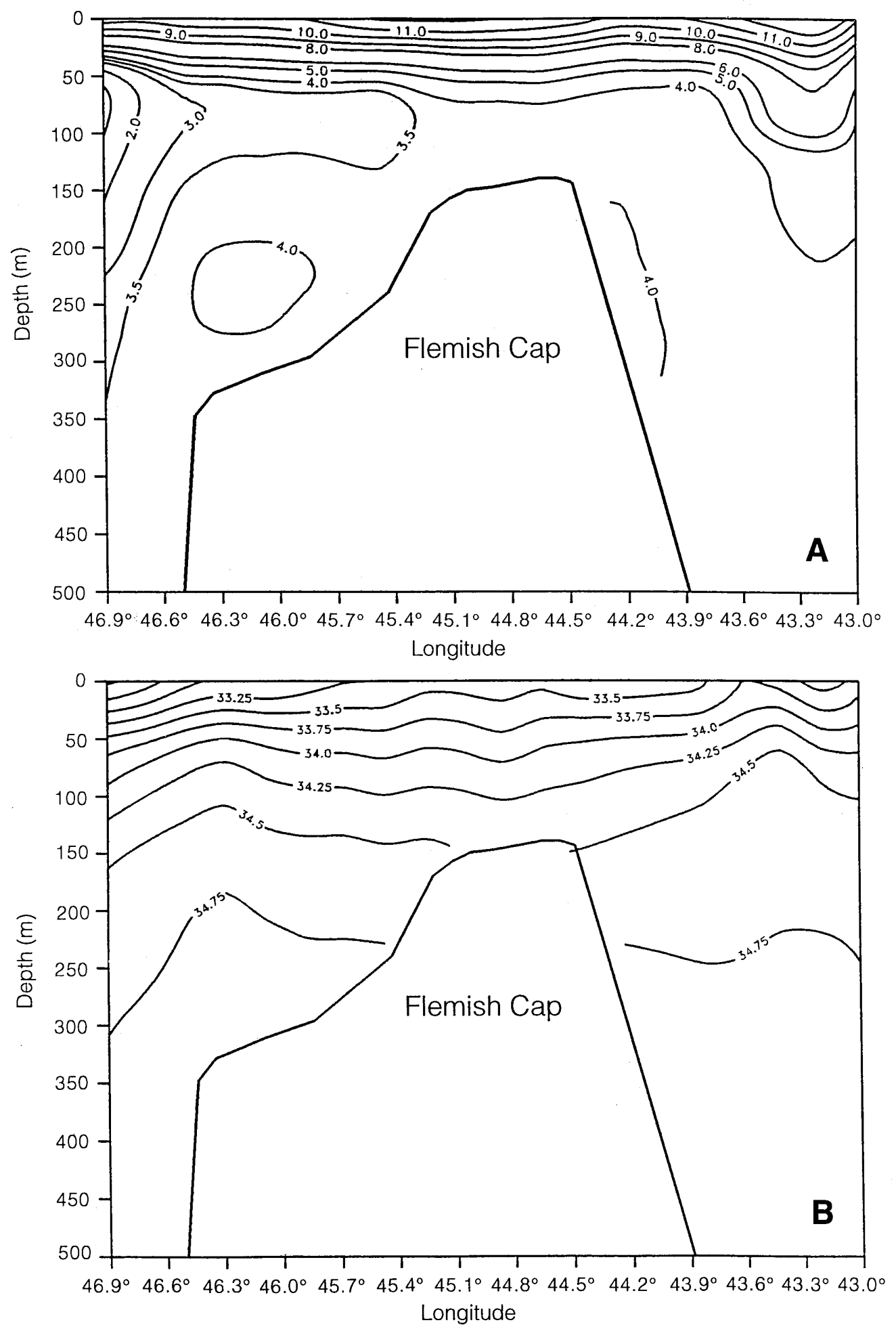

Fig. 4. Vertical distribution of the average (A) temperature and (B) salinity over the Flemish Cap in July along $47^{\circ} \mathrm{N}$ based on all available historical data from 1961-90 (from Colbourne, MS 1996). 
peak amplitudes reaching $3.0^{\circ} \mathrm{C}$ below normal at depths to $50 \mathrm{~m}$. This cold period moderated briefly in 1987 but continued to the summer of 1993 with anomalies reaching $2.0^{\circ} \mathrm{C}$ below normal by July of 1993. The time series of salinity anomalies (Fig. 5B) showed large, fresher than normal conditions from 1971 to 1976 and from 1983 to 1986 in the upper 100 to $200 \mathrm{~m}$ of the water column with peak amplitudes reaching 0.5 PSU below normal. Salinities during the early-1990s appeared to be about normal. Like the temperature anomalies, the salinity anomaly amplitude was maximum in the upper mixed layers where the effect of ice melt is the largest. Anomalies of both temperature and salinity were very small at depths greater than $200 \mathrm{~m}$.

\section{General Biology of $P$. borealis}

In the Northwest Atlantic, P. borealis occurs from Georges Bank (about $41^{\circ} \mathrm{N}$ ) to Davis Strait (about $72^{\circ} \mathrm{N}$ ), and supports fisheries in the following areas: Gulf of Maine, Scotian Shelf, Gulf of St. Lawrence, Newfoundland-Labrador and both sides of Davis Strait. Distribution continues through East Greenland, Iceland and the Northeast Atlantic, including the Norwegian, Barents and North Seas (Parsons, MS 1982). The species also has been reported from the Pacific in areas off British Columbia (Butler, 1980), Japan (Ito, 1976) and eastern Russia (Kitano and Yorita, 1978), although Squires (1992) recognized the Pacific form as a separate
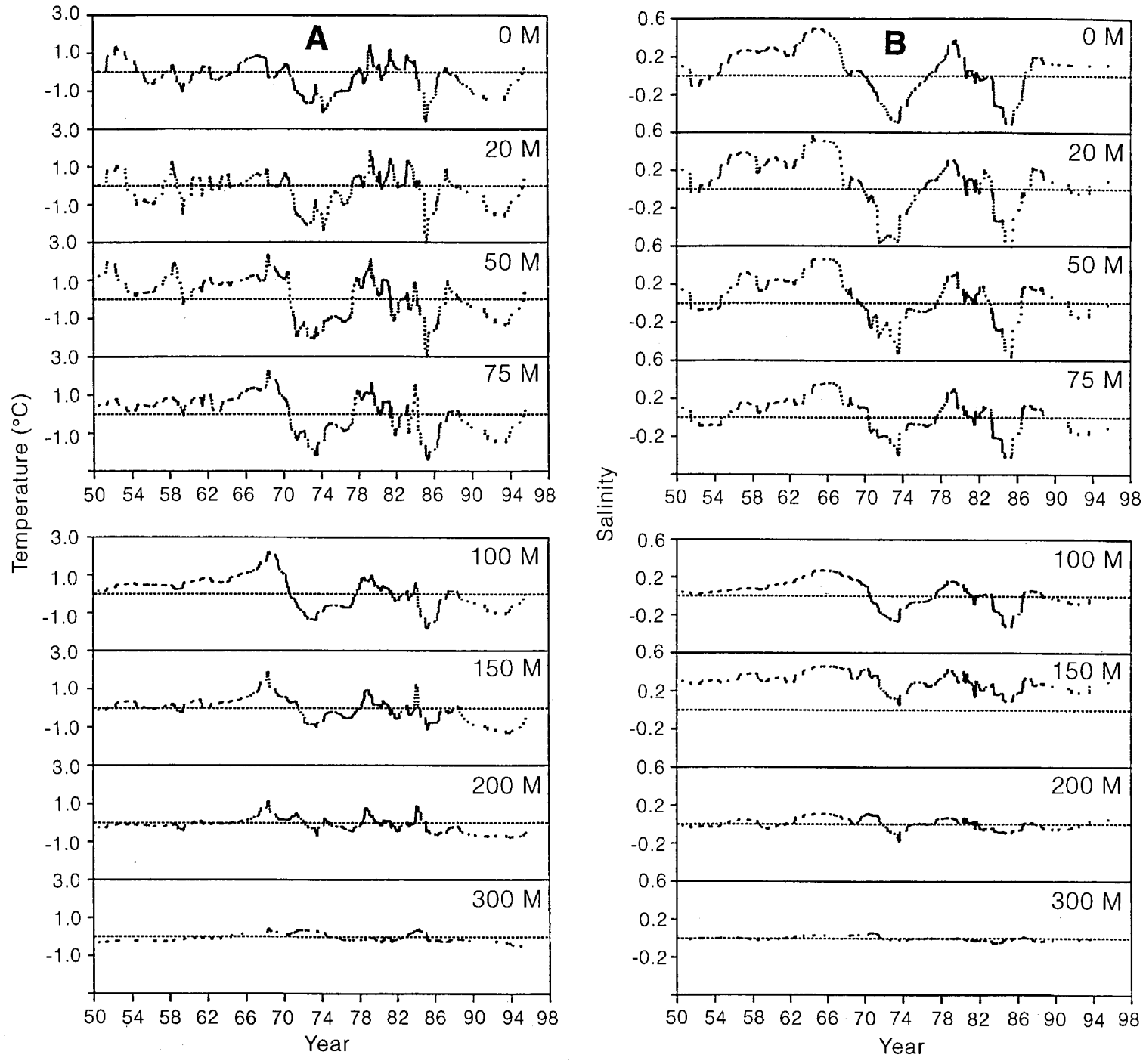

Fig. 5. Time series of (A) temperature and (B) salinity anomalies on the Flemish Cap at standard depths (adapted and updated from Colbourne, 1993). 
species, Pandalus eous, based on morphological differences in adults and size differences in larvae.

Allen (1959) observed that substrate, temperature, salinity and depth are factors that influence the distribution of $P$. borealis. The species is usually associated with soft, muddy substrates (Butler, 1971) and has been found in temperatures generally between $3^{\circ}$ and $8^{\circ} \mathrm{C}$ (Rasmussen, 1965), but occasionally as cold as $-1.68^{\circ} \mathrm{C}$ and as warm as $11.13^{\circ} \mathrm{C}$ (Allen, 1959), in salinities between 25.9 and 35.7 PSU (Butler, 1971) and in depths from less than $10 \mathrm{~m}$ to greater than $1300 \mathrm{~m}$ (Butler, 1971).

The species is a protandric hermaphrodite (Berkeley, 1930). It matures as a male as early as age 1 and functions as such for one or more years. It then passes through a transitional stage when sex change occurs and spends the rest of its life as a female. Age at sex change is variable within and among populations. In some, the male phase is suppressed (Butler, 1971) while, in others, sex inversion from male to female might not occur (Squires, 1968).

The species migrates vertically, especially at night (Allen, 1959). This migration has been associated with a pelagic phase of feeding based on the occurrence of pelagic prey species in stomachs (Horsted and Smidt, 1956; Barr, 1970; Berenboim, 1981; Wienberg, 1981; Hopkins et al., 1993). However, shrimp are also known to feed while on the bottom.

Biological differences among populations are evident along a latitudinal gradient. Generally, northern populations exhibit a slower rate of growth, delayed maturation and greater longevity (Rasmussen, 1953; Horsted and Smidt, 1956; Squires, 1968; Apollonio and Dunton, MS 1969; Haynes and Wigely, 1969; Shumway et al., 1985). The mature male phase may last for several years. Females in northern populations have been aged to $8+$ years and attain maximum sizes which are greater than those seen in some southern areas.

\section{The Shrimp Fishery}

The fishery for northern shrimp on Flemish Cap began in late-April, 1993 when two Canadian vessels were granted exploratory permits to fish the species in NAFO Div. 3M. The only known commercial activity targeting shrimp prior to 1993 was in 1990 when two Canadian vessels fished unsuccessfully in April and May.

\section{Fishing Technology}

Quantitative information on the relative fishing power of ships used in this fishery by the different nations is lacking. Some nations operate small, inefficient vessels which might have been designed originally for fishing species other than shrimp. Such vessels report daily catches usually in the range of 2 to 4 tons. Other vessels are technologically advanced and in some instances were built specifically to harvest shrimp. These often catch 10 or more tons a day. All vessels tow otter trawls with small mesh to retain the shrimp. Some of the larger vessels tow two complete trawls simultaneously. This was first reported for an Icelandic trawler in 1994 (Skuladottir, MS 1994) and later for several Greenlandic (Siegstad and Hvingel, MS 1995) and Faroese vessels (NAFO, 1995b). Sorting grates to minimize by-catch were made mandatory by the NAFO Conservation and Enforcement Measures for this fishery beginning in 1994 and maximum bar spacing was reduced from $28 \mathrm{~mm}$ in 1994 to $22 \mathrm{~mm}$ in 1995 (see below).

\section{Regulations}

No NAFO regulations were imposed on the shrimp fishery in Div. 3M in 1993 but individual nations might have applied some for their own vessels. The rapid expansion of the fishery prompted NAFO Scientific Council to conduct an initial assessment of the resource in September, 1993. The Council concluded that data were insufficient to provide a basis for the calculation of a TAC but advocated a cautious approach to exploitation, given the potential for high fishing mortality. No preemptive or precautionary catch or effort limits were recommended or implemented for 1994 by the Fisheries Commission. In its considerations in 1993, Scientific Council also was concerned that the by-catch of small redfish in the new shrimp fishery might significantly impact the redfish resource and recommended a mandatory and immediate use of sorting grates to minimize the by-catch problem. This recommendation was implemented by the Fisheries Commission in 1994 and maximum bar spacing was specified at $28 \mathrm{~mm}$ (NAFO, MS 1993). In addition, a minimum mesh size was established at $40 \mathrm{~mm}$; vessels were required to change fishing area immediately by a minimum of 5 naut. miles if bycatches of all regulated groundfish species in any 
haul exceeded $10 \%$ by weight; and observer coverage was required for a minimum of $10 \%$ of a Contracting Party's total estimated fishing days on ground for shrimp. Contracting Parties were further instructed to ensure that their vessels not conduct a directed fishery for shrimp in Div. 3LNO in 1994.

Scientific Council conducted its second assessment of shrimp in Div. 3M in September, 1994, but there was still no basis for the calculation of a TAC. Lower catch rates and smaller shrimp encountered over an expanded fishing area in 1994 were considered reflective of intensive fishing and the Council agreed that a reduction in effort would be required to protect younger animals at lower stock size (NAFO, 1995b). However, no regulations to effectively reduce exploitation were introduced for 1995. By-catch of small redfish in the fishery continued to be a problem because grates with $28 \mathrm{~mm}$ bar spacings did not eliminate by-catch of redfish less than $21 \mathrm{~cm}$ (NAFO, 1995b). The Fisheries Commission revised the Conservation and Enforcement Measures from the previous year, reducing maximum bar spacing to $22 \mathrm{~mm}$ and the by-catch limit for all regulated groundfish species to 5\% (NAFO, MS 1994b).

By September, 1995, data on distribution of fishing effort and size composition of the catches showed clearly that the fishing pattern had changed between years. The fishing grounds were expanded over a broader range of depths and effort was being redirected toward small, male shrimp as young as age 2 (about $15 \mathrm{~mm}$ carapace length (CL)). Scientific Council could find no practical way to protect the younger animals in the short term other than to close the fishery in 1996. This recommendation was not accepted and, instead, Fisheries Commission implemented effort control. Each Contracting Party was instructed to limit the number of vessels in 1996 to the number that participated in the fishery from 1 January 1993 to 31 August 1995 and to limit the number of fishing days to the maximum number of fishing days observed for their vessels in one of the years 1993, 1994 or up to 31 August 1995 (NAFO, MS 1995). Further, Contracting Parties with no previous record of fishing shrimp in Div. 3M were permitted 100 fishing days by one vessel in 1996 and those with a small track record were permitted an equal number of days. Other management measures from 1994 were reiterated for the 1996 fishery.

\section{Catch, Effort and Catch-Per-Unit-Effort (CPUE)}

Catches and sizes of shrimp in spring, 1993, were acceptable by industry standards despite some initial problems with animals having soft shells and pale colour. By late-July, about 50 vessels from up to nine nations were reported fishing for shrimp in the area. The number of vessels decreased over the remainder of the year and only 4 were reported fishing shrimp at the end of December (Parsons, MS 1994). The nominal catch of shrimp from Div. 3M in 1993 was estimated at approximately 28000 tons.

Fishing continued into 1994 at low intensity. The number of vessels increased from 4 during the first week of January to 17 by late-February and remained near that level until early-April, decreasing shortly thereafter. From mid-April to mid-June, the number of vessels increased from 7 to 47 and then decreased steadily to 3 at the end of the year (Parsons, MS 1995). The catch in 1994 was estimated at just over 24000 tons.

In 1995, activity was low throughout the January-March period (3 to 8 vessels) but increased substantially from 7 vessels in early-April to 71 by late-July. The number declined steadily over the remainder of the year to 6 during the last week of December (Parsons, MS 1996). The estimated 1995 catch was approximately 33000 tons.

At least 13 nations participated from the start of the fishery in spring of 1993 to the end of 1995. Largest catches were taken by Norway, the Faroe Islands and Iceland (Table 1).

Fishing effort has been distributed around the bank, concentrated near the $400 \mathrm{~m}$ contour. Figure 6 illustrates the area fished for shrimp on the Flemish Cap based on set by set observations from the Canadian (1993-95) and Norwegian (1995) fleets. It is assumed that the fishing activity of Canadian and Norwegian vessels was representative of the total fleet. The fishing grounds for observed activity covered a total of $23500 \mathrm{~km}^{2}$ on the east, west and northern portions of the bank at depths between 151 and $620 \mathrm{~m}$. Ninety percent of the activity occurred over about $11000 \mathrm{~km}^{2}$ between 275 and 475 $\mathrm{m}$. Areas fished differed among years, covering 11 $600 \mathrm{~km}^{2}$ and a narrow depth range $(300-500 \mathrm{~m})$ in 1993 and $12600 \mathrm{~km}^{2}$ in 1994 . There was little fishing activity on the eastern slope in 1994 and an 
TABLE 1. Estimates of catches (tons) of northern shrimp, Pandalus borealis, by year and country - 1993 to 1995 .

\begin{tabular}{lrrr}
\hline \hline Nation & 1993 & 1994 & 1995 \\
\hline Canada & 3724 & 1041 & 970 \\
Denmark & 800 & 400 & 200 \\
Portugal & 0 & 0 & 150 \\
Spain & 240 & 300 & 158 \\
Estonia & 0 & 1081 & 2092 \\
Faroe Islands & 8545 & 6567 & 5987 \\
Greenland & 3788 & 2276 & 2403 \\
Honduras & 1265 & 0 & 0 \\
Iceland & 243 & 2300 & 7623 \\
Latvia & 0 & 300 & 350 \\
Lithuania & 0 & 1225 & 675 \\
Norway & 7183 & 8460 & 9534 \\
Russia & 300 & 300 & 2838 \\
St. Vincent & 0 & 75 & 0 \\
Total & 28088 & 24325 & 32980 \\
\hline
\end{tabular}

expansion of the grounds to the southwest, compared to 1993. In 1995, the grounds covered a considerably larger area $\left(18700 \mathrm{~km}^{2}\right)$ with a greater range of depths fished $(200-500 \mathrm{~m})$ and further expansion in the southwest. Fishing in deeper water $(>600 \mathrm{~m})$ has been reported occasionally in the southwest (Flemish Pass), at times extending into Div. 3L.

In 1993 annual catch rates calculated from vessel logbook data for Canada and Greenland (about $400 \mathrm{~kg} / \mathrm{hr}$ ) were higher than those reported for Iceland and Norway (about $300 \mathrm{~kg} / \mathrm{hr}$ ). Canadian surveillance reports indicated that Russian catch rates were very low compared to all other fleets. Catch rates declined over at least part of the season for several fleets. Canadian monthly averages showed a large decline from May to July, Greenland from May to September, Iceland from June to October and Norway from May to November (Parsons, MS 1994).

In 1994, Canada, Greenland, Iceland and Norway experienced similar mean catch rates, ranging from about 220 to $260 \mathrm{~kg} / \mathrm{hr}$. Those for Estonia and Latvia were considerably lower (about $140 \mathrm{~kg} / \mathrm{hr}$ ). Seasonal trends in catch rates also occurred in 1994. Estonian and Norwegian vessels, which fished throughout the year, produced variable or increasing catch rates up to May, followed by an overall decrease to the end of the year. Canadian and Latvian CPUE estimates for the February-June period increased while those for Greenland decreased from May to September. Icelandic rates were generally variable without trend up to August but declined thereafter (Parsons, MS 1995).

In 1995, the Canadian catch rate $(272 \mathrm{~kg} / \mathrm{hr})$ was slightly higher than the 1994 value but lower than the 1993 estimate. Monthly CPUE increased from March to May and then declined from May to July. Estonian catch rates in February and March $(160-170 \mathrm{~kg} / \mathrm{hr})$ were higher than those for the same months in 1994 but, for the April-July period, the 1995 values were lower. A slight decrease occurred from May to August. The Greenlandic annual rate for 1995, when adjusted for double trawls $(289 \mathrm{~kg} /$ hr), was higher than the 1994 value but lower than in 1993. Monthly CPUE increased during the MayJuly period. Icelandic monthly rates were variable in $1995(130-280 \mathrm{~kg} / \mathrm{hr})$ and generally lower than those of the previous two years in months where comparisons were possible (Parsons, MS 1996).

Overall, the catch rate data showed considerable variation by fleet, season and year. Vessels from Canada and Nordic nations consistently achieved higher catch rates than those of Baltic vessels. Within fleets, CPUE increased to about May but declined, thereafter, to the end of the year. The 1995 annual CPUE's for most fleets were about the same or slightly higher than the 1994 values, but remained substantially lower than those of 1993. Such sources of variation must be taken into account when interpreting catch rate data as indices of abundance, especially given the expansion of the 

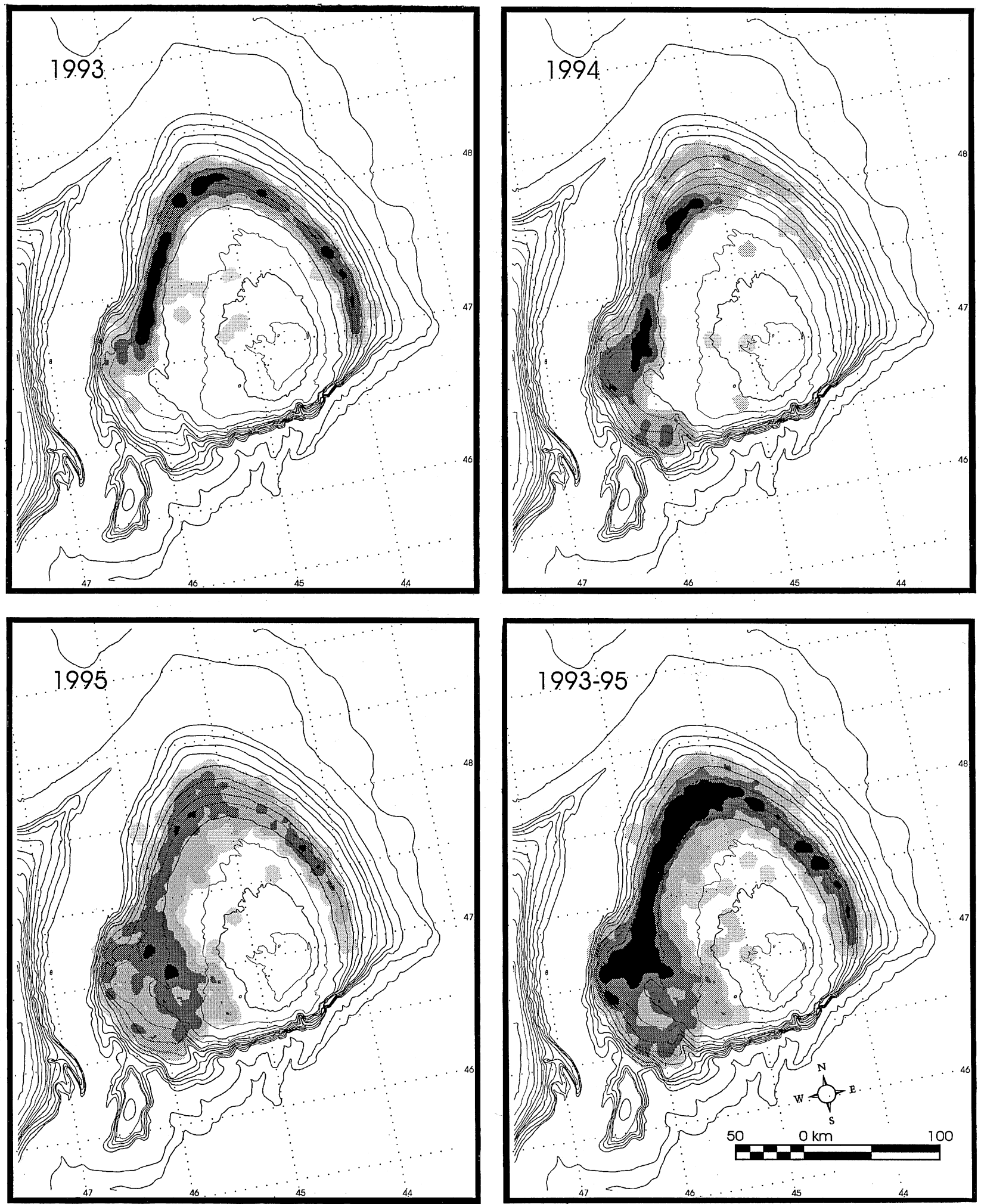

Fig. 6. Fishing grounds for northern shrimp in NAFO Div. 3M, 1993-95. Black areas denote highest concentration of fishing effort. Increasingly lighter shades indicate decreasing effort density. Depth contours are $50 \mathrm{~m}$ intervals (light lines are 150,250, 350 and 450) up to $450 \mathrm{~m}$ then at $100 \mathrm{~m}$ intervals to $1000 \mathrm{~m}$, plus 2000 and $3000 \mathrm{~m}$. 
fishing area into shallower depths over the brief, three-year period.

\section{By-catch}

The small-meshed otter trawl used to catch shrimp frequently results in the incidental capture of fish and other invertebrate species. In Div. 3M, reports of high by-catches from the new shrimp fishery raised concerns in NAFO about the potential damage to groundfish stocks, particularly redfish. In 1994, the Fishery Commission requested information on the potential loss of yield for redfish due to by-catch mortality and the Scientific Council calculated yield losses based on a previous yieldper-recruit analysis for the Div. 3LN stock (NAFO, 1995b). More than 30000 tons lost yield were projected at both $\mathrm{F}_{0.1}$ and $\mathrm{F}_{\max }$, assuming a shrimp catch of 30000 tons and a redfish by-catch of $20 \%$. The Council stated that all losses would be spread out over about 15 years but would, in an equilibrium situation, represent annual losses. Losses greater than 20000 tons would only be realized for strong redfish year-classes.

Fishery observers were deployed on all Canadian vessels during 1993-95 and some Norwegian vessels in 1995. However, the percentage of activity observed for all countries combined was only $8 \%$ in 1993, 4\% in 1994 and 5\% in 1995. Observers recorded details of the catches on a set-by-set basis and this information was used to examine catch and discarding of by-catch.

The weight of each species taken in each set was estimated by sampling the total catch according to methods outlined in Kulka (MS 1996) and Kulka and Firth (MS 1987). Maps of fishing grounds were produced by converting point data (in this case, set-by-set fishing locations) to effort density surfaces using potential mapping of SPANS, similar to the methods of Kulka et al. (1995) and Kulka and Power (MS 1996). Similarly, potential maps of shrimp and redfish were produced from setby-set estimates of catch per hour to illustrate distribution of the two species on the fishing grounds.

Table 2 lists the estimated total catch by species from the observed shrimp fishery adjusted to the total shrimp catches of all countries for each year, assuming proportions of by-catch were similar among fleets. The quantity of by-catch, as a percentage of total catch, declined from 33.3\% in 1993 to $21.9 \%$ in 1994 and to $2.6 \%$ in 1995 . Of the com- mercially important species, redfish (Sebastes sp.) was found to dominate the by-catch. No other species accounted for more than $1 \%$ of the catch in any year. The percentage of the total redfish catch declined from $28.4 \%$ in 1993 to $19 \%$ in 1994 and $1.1 \%$ in 1995 . In 1995 , with use of $19-22 \mathrm{~mm}$ grates, the dominant by-catches were small or thin fish, such as young redfish, lanternfish and eelpout that are of similar width to shrimp.

Significant changes occurred in the configuration of the fishing gear among years related to the mandatory use of sorting grates in 1994 and changes in bar spacings in the grates between 1994 and 1995. In $1994,75 \%$ of the sets observed had $28 \mathrm{~mm}$ spacing while $10 \%, 10 \%$ and $5 \%$ were 27,26 and $25 \mathrm{~mm}$, respectively. In $1995,61 \%, 7 \%$ and $31 \%$ of sets had 22, 20 and $19 \mathrm{~mm}$ spacing. In 1994, the percent of redfish by-catch increased with decreasing grid size between 28 and $26 \mathrm{~mm}$ but was lowest at $25 \mathrm{~mm}$. In 1995, redfish by-catch was less than 3\%, regardless of grate size used (Fig. 7). The greatest differences were among years rather than among grate space categories within years.

Some differences were observed between the distribution of shrimp (Fig. 8) and redfish (Fig. 9). In 1993, high by-catches of redfish (>50 kg per hr) were distributed over $83 \%\left(9600 \mathrm{~km}^{2}\right)$ of the total grounds including all of the west and northwest areas. The densest shrimp concentrations $(>500 \mathrm{~kg}$ per hr) were located over a less extensive area (3 $500 \mathrm{~km}^{2}$ ) of the western and northern parts of the Flemish Cap. An overlay of shrimp and redfish catch distributions (Fig. 10) shows two patches of high shrimp catch with low redfish by-catch in 1993. Areas of high by-catch and low shrimp catch tended to be found on the periphery of the grounds. For 1994, high shrimp catches were attained in only $2 \%$ of the area while high by-catches of redfish covered $33 \%$ of the grounds. High shrimp/low bycatch areas were more patchy than in 1993 and were located on the inner portion of the northern area and on the southern extension of the grounds. In 1995, the high shrimp/low by-catch areas were located mainly to the shallower northwest and southwest areas not previously fished. Redfish catch rates within the shrimp fishing grounds did not show any trend with depth.

Measurements of redfish taken in shrimp trawls during May, 1993 showed a single mode of small fish at $14 \mathrm{~cm}$ (Parsons et al., MS 1993). This size 
TABLE 2. Estimates of total catches (tons) by species from the observed shrimp fishery on Flemish Cap adjusted to the total estimated shrimp catches of all countries for the years 1993, 1994 and 1995.

\begin{tabular}{|c|c|c|c|c|c|c|c|c|}
\hline \multirow{2}{*}{$\begin{array}{l}\text { Species } \\
\text { Common name }\end{array}$} & \multicolumn{2}{|c|}{1993} & \multicolumn{2}{|c|}{1994} & \multicolumn{2}{|c|}{1995} & \multicolumn{2}{|c|}{ Average } \\
\hline & Catch & Percent & Catch & Percent & Catch & Percent & Catch & Percent \\
\hline Shrimp & 28088.0 & 66.74 & 24325.0 & 78.15 & 32980.0 & 97.41 & 28464.3 & 80.8 \\
\hline Redfish & 11970.0 & 28.44 & 5902.7 & 18.96 & 374.2 & 1.11 & 6082.3 & 16.2 \\
\hline Greenland halibut & 309.2 & 0.73 & 96.7 & 0.31 & 32.2 & 0.10 & 146.0 & 0.4 \\
\hline Spotted wolffish & 392.5 & 0.93 & 20.3 & 0.07 & 12.5 & 0.04 & 141.8 & 0.3 \\
\hline Skates & 354.2 & 0.84 & 22.8 & 0.07 & 12.2 & 0.04 & 129.7 & 0.3 \\
\hline Striped wolffish & 176.8 & 0.42 & 69.0 & 0.22 & 56.4 & 0.17 & 100.7 & 0.3 \\
\hline Lanternfish & 70.2 & 0.17 & 63.6 & 0.20 & 144.7 & 0.43 & 92.8 & 0.3 \\
\hline Eelpout & 38.5 & 0.09 & 82.4 & 0.26 & 75.8 & 0.22 & 65.6 & 0.2 \\
\hline Common grenadier & 5.5 & 0.01 & 79.7 & 0.26 & 27.3 & 0.08 & 37.5 & 0.1 \\
\hline Roughhead grenadier & 15.8 & 0.04 & 75.9 & 0.24 & 7.8 & 0.02 & 33.2 & 0.1 \\
\hline Greenland shark & 46.6 & 0.11 & 50.1 & 0.16 & 0.0 & 0.00 & 32.2 & 0.1 \\
\hline Capelin & 65.5 & 0.16 & 12.8 & 0.04 & 2.7 & 0.01 & 27.0 & 0.1 \\
\hline Plaice & 59.9 & 0.14 & 11.1 & 0.04 & 6.4 & 0.02 & 25.8 & 0.1 \\
\hline Northern wolffish & 69.7 & 0.17 & 0.2 & 0.00 & 0.0 & 0.00 & 23.3 & 0.1 \\
\hline Witch flounder & 31.9 & 0.08 & 12.1 & 0.04 & 5.3 & 0.02 & 16.4 & 0.0 \\
\hline Longfish hake & 14.1 & 0.03 & 24.6 & 0.08 & 5.8 & 0.02 & 14.8 & 0.0 \\
\hline Viperfish & 10.1 & 0.02 & 19.6 & 0.06 & 5.7 & 0.02 & 11.8 & 0.0 \\
\hline Basking shark & 35.3 & 0.08 & 0.0 & 0.00 & 0.0 & 0.00 & 11.8 & 0.0 \\
\hline Lancetfish & 24.5 & 0.06 & 3.0 & 0.01 & 6.1 & 0.02 & 11.2 & 0.0 \\
\hline Snipe eel & 10.4 & 0.02 & 15.9 & 0.05 & 2.1 & 0.01 & 9.5 & 0.0 \\
\hline Barracudina & 4.0 & 0.01 & 15.9 & 0.05 & 7.3 & 0.02 & 9.1 & 0.0 \\
\hline Cod & 18.9 & 0.04 & 2.3 & 0.01 & 0.3 & 0.00 & 7.2 & 0.0 \\
\hline Roundnose grenadier & 10.4 & 0.02 & 10.3 & 0.03 & 0.1 & 0.00 & 6.9 & 0.0 \\
\hline Silver hake & 0.1 & 0.00 & 17.4 & 0.06 & 0.0 & 0.00 & 5.8 & 0.0 \\
\hline Halibut & 8.0 & 0.02 & 0.0 & 0.00 & 0.0 & 0.00 & 2.7 & 0.0 \\
\hline Other & 255.6 & 0.61 & 192.4 & 0.62 & 92.1 & 0.27 & 180.0 & 0.5 \\
\hline Total & 42085.9 & & 31125.8 & & 33856.8 & & 35689.5 & \\
\hline
\end{tabular}

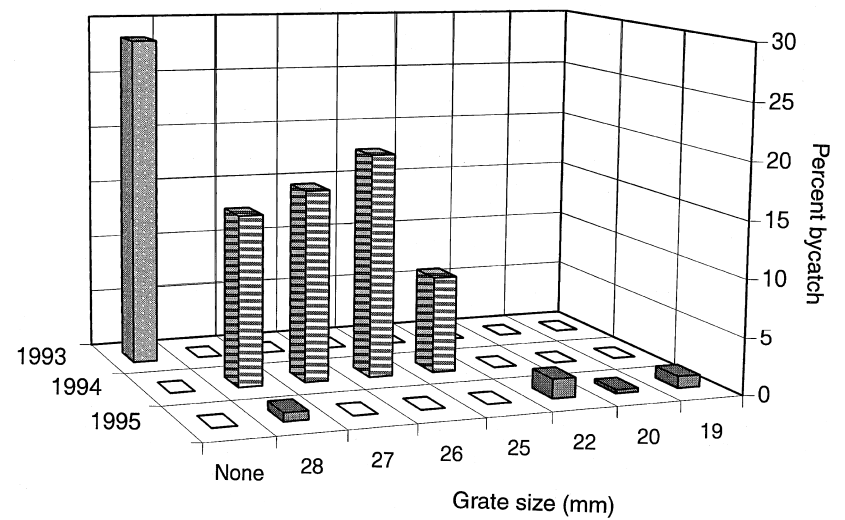

Fig. 7. Percent of redfish in the NAFO Div. $3 \mathrm{M}$ shrimp fishery by grate size and year.

group, possibly representing one or two year-classes produced in the late-1980s (Saborido-Rey, MS 1995), also was evident in June and July but was accompanied by larger/older fish forming modes at $23 \mathrm{~cm}$ in June and $19 \mathrm{~cm}$ in July. Redfish caught from April to June, 1994, despite the mandatory sorting grate (28 $\mathrm{mm}$ bar spacings), were unimodal at $17-18 \mathrm{~cm}$ and were presumed to belong, primarily, to the same late-1980s year-class or yearclasses discussed above. In 1995, bar spacings were reduced to $22 \mathrm{~mm}$ or less and redfish by-catch was very low compared to the previous two years (Parsons and Veitch, MS 1995; Siegstad and Hvingel, MS 1995).

Length samples of redfish collected by observers in 1993, 1994 and 1995 were used to estimate the numbers discarded from the shrimp fishery each year (Fig. 11). In 1993, an estimated 227.6 million redfish with modal length of $14 \mathrm{~cm}$ were caught as by-catch and discarded. Estimates of 89.1 million and 4.8 million redfish with average length of about $18 \mathrm{~cm}$ were taken in 1994 and 1995, respectively. 

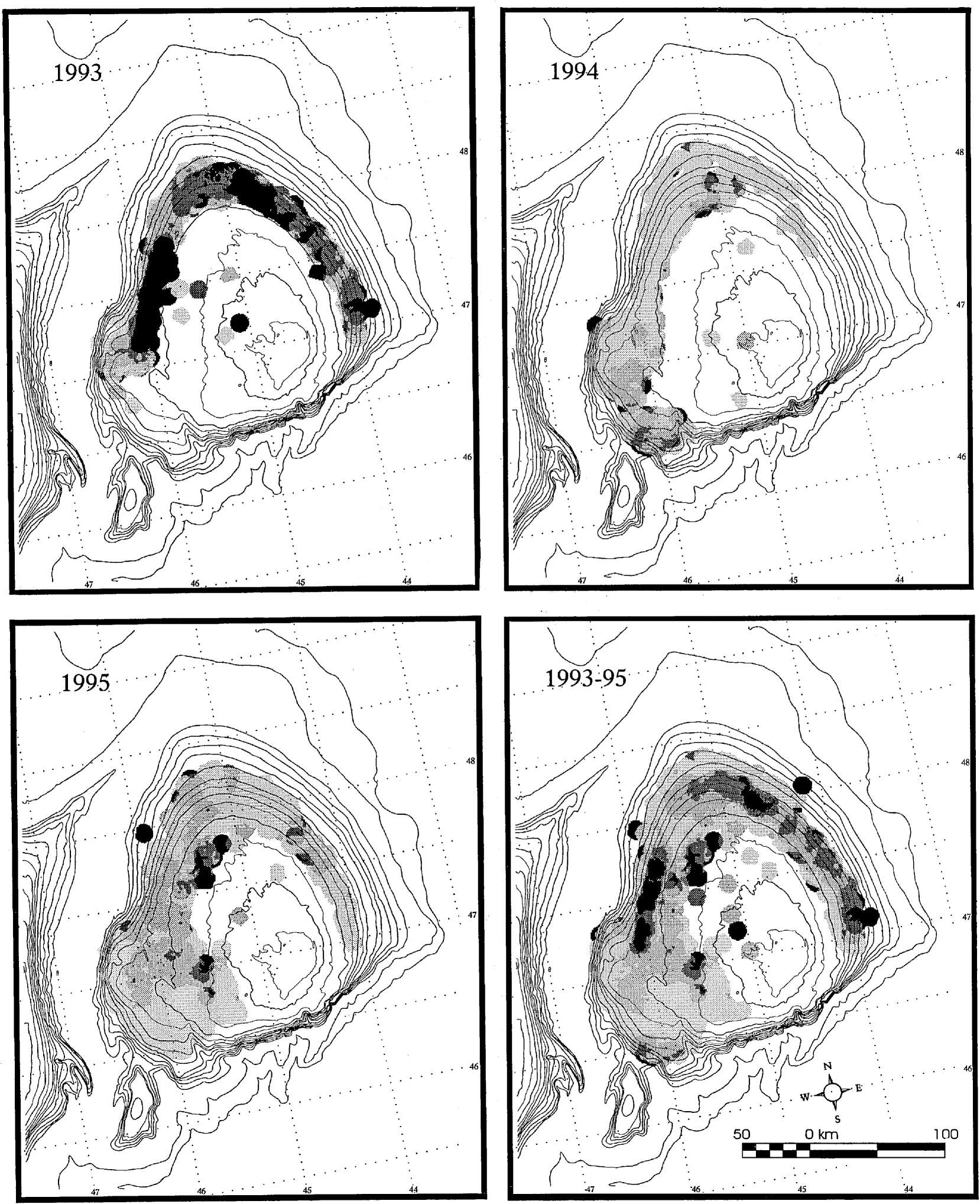

Fig. 8. Density of shrimp in NAFO Div. 3M, 1993-95. Black areas denote areas where kg per hr in the fishery exceeded 500, dark grey, 400-500, medium grey, 300-400 and light grey less than 300. Depth contours are $50 \mathrm{~m}$ intervals (light lines are 150,250,350 and 450) out to $450 \mathrm{~m}$ then at $100 \mathrm{~m}$ intervals to $1000 \mathrm{~m}$, plus 2000 and $3000 \mathrm{~m}$. 

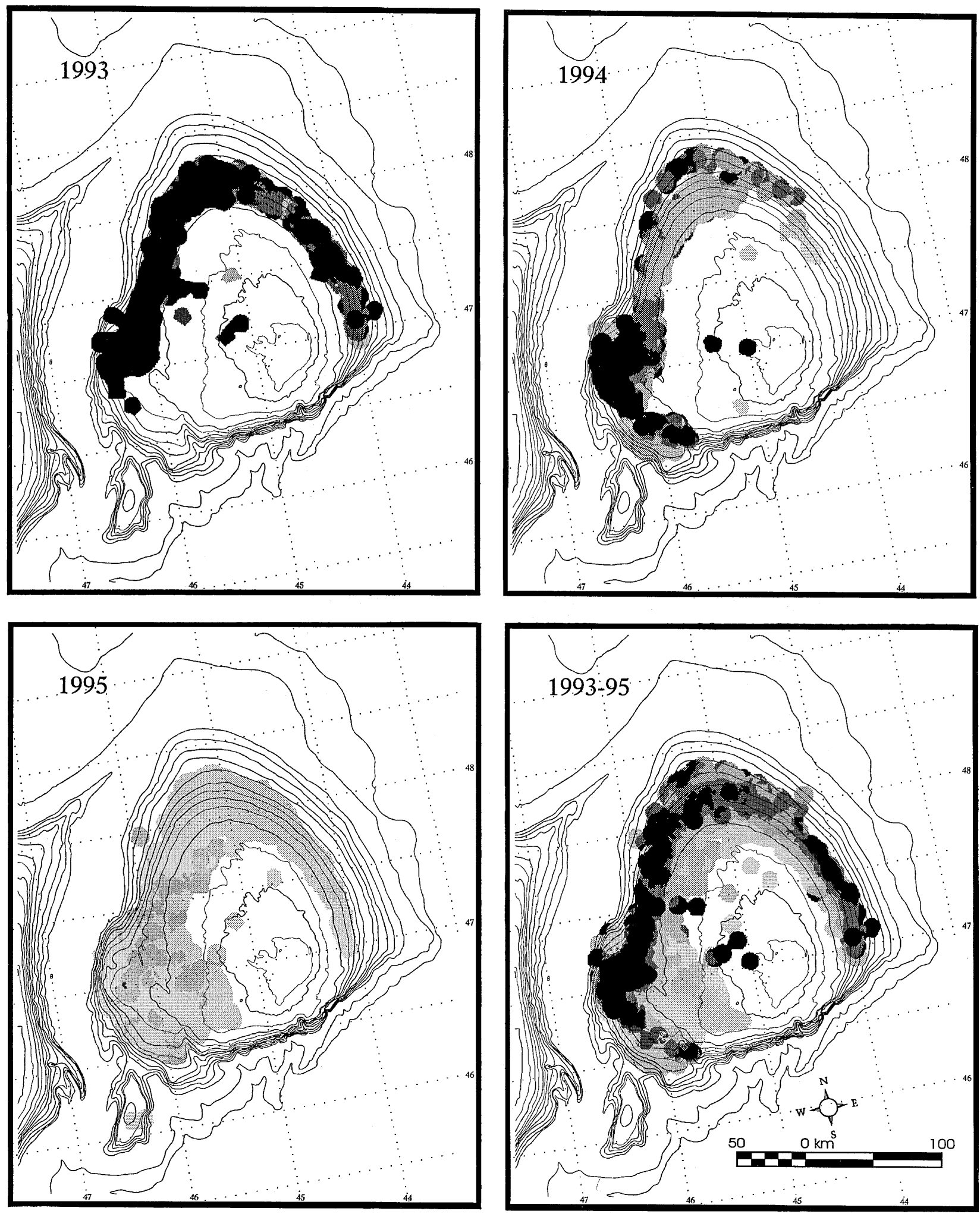

Fig. 9. Density of redfish in the northern shrimp fishery in NAFO Div. 3M, 1993-95. Black areas denote areas where $\mathrm{kg}$ per hr exceeded 50, dark grey, 30-50, medium grey, 7-30 and light grey less than 7. Depth contours are $50 \mathrm{~m}$ intervals (light lines are 150,250,350 and 450) out to $450 \mathrm{~m}$ then at $100 \mathrm{~m}$ intervals to $1000 \mathrm{~m}$, plus 2000 and $3000 \mathrm{~m}$. 

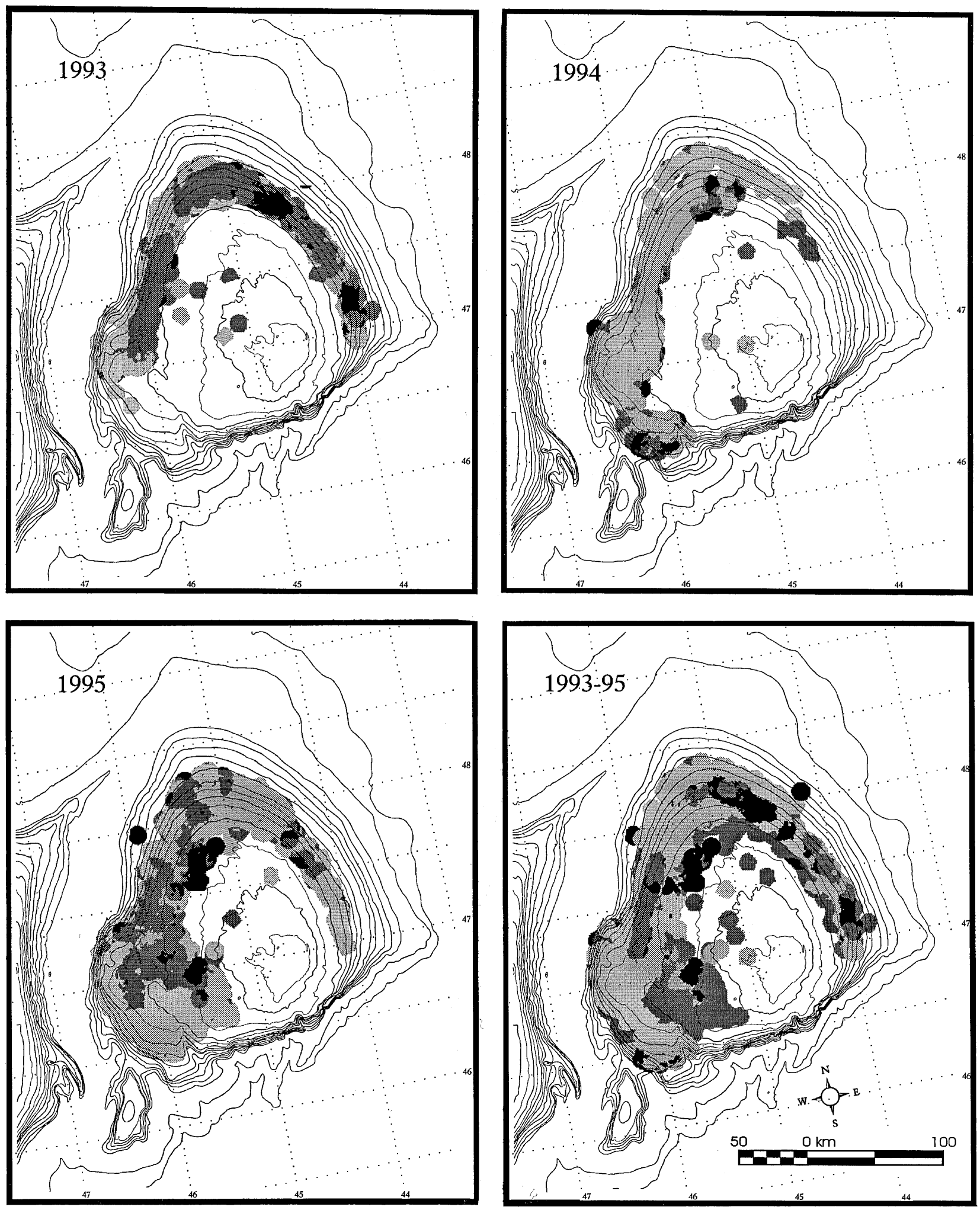

Fig. 10. Overlay of shrimp and redfish. Black indicates high shrimp catch/low redfish by-catch and light grey indicates low shrimp catch/high redfish by-catch. 


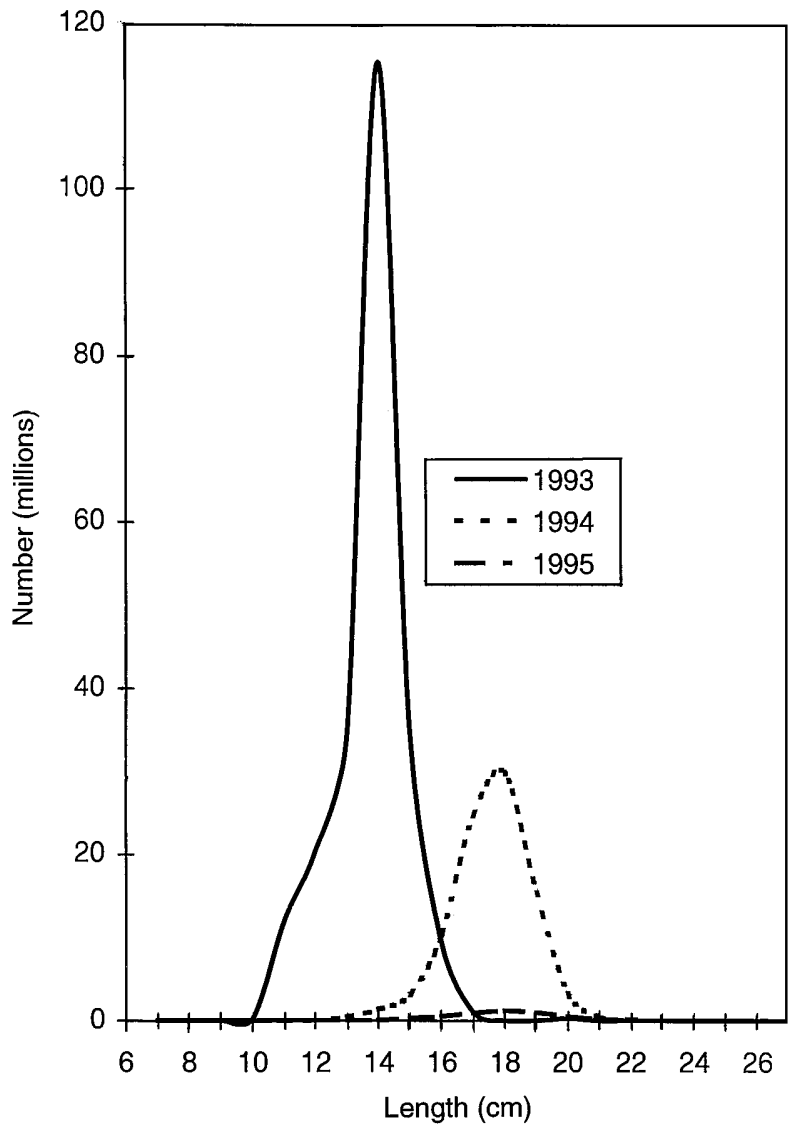

Fig. 11. Numbers at length for redfish taken as by-catch from the 1993, 1994 and 1995 shrimp fisheries in NAFO Div. $3 \mathrm{M}$.

\section{Biology of P. borealis on Flemish Cap}

\section{Distribution}

Research bottom-trawl surveys on Flemish Cap by EU-Spain have been conducted since 1988 (Vazquez, MS 1989; Sainza, MS 1995) using a standardized survey method. These surveys were designed for demersal fish but also provided information on distribution and relative abundance of shrimp because a codend liner with $35 \mathrm{~mm}$ mesh was used.

Survey results show that shrimp are found around the bank with highest densities in the western, northern and northeastern areas at depths between approximately 250 and $550 \mathrm{~m}$ (Escalante et al., MS 1990; Mena, MS 1991, MS 1992; Sainza, MS 1993a,b, MS 1994, MS 1995). Slopes in the south and southeast appear to be sparsely populated (Fig. 12). The surveys also provided length distributions for each stratum fished which showed that smaller, male shrimp were more prevalent in depths less than $400 \mathrm{~m}$, a mixture of sizes and sexes occurred between 400 and $500 \mathrm{~m}$ and the larger, female shrimp dominated in depths greater than 500 m (Escalante et al., MS 1990; Sainza, MS 1993a, b, MS 1994, MS 1995).

The shrimp fishery on Flemish Cap also provided information on distribution. Areas and depths $(250-500 \mathrm{~m})$ which attract the most fishing effort reflect, to some extent, the densest concentrations of marketable shrimp. Little or no fishing occurred in the southern and southeastern areas of the bank (Nicolajsen, MS 1993, MS 1994a, MS 1995; Parsons and Veitch, MS 1994, MS 1995; Parsons et al., MS 1993; Siegstad, MS 1993, MS 1994; Siegstad and Hvingel, MS 1995), consistent with the general scarcity of shrimp seen in the EU-Spain survey data. The fishery in 1995 extended into shallower waters (200-300 m) of the western grounds where small, male shrimp were abundant (NAFO, 1996) (Fig. 6 and 8).

Lilly (MS 1993) calculated partial fullness indices for shrimp found in cod stomachs during 1980-83 on Flemish Cap and showed that shrimp were present in stomachs of cod caught in depths of 250-500 m, consistent with the findings of the EU-Spain research trawl surveys and inferences from the commercial fishery. Occurrence of shrimp was low in cod caught on top of the bank but shrimp distribution at depths beyond $500 \mathrm{~m}$ was difficult to infer because cod catches were low at those depths.

\section{Biomass}

Relative biomass estimates for shrimp on Flemish Cap, calculated by areal expansion, are available from trawl surveys conducted since 1988 (Sainza, MS 1995). From 1988 to 1990, biomass appeared to be stable at an index of about 2000 tons (Table 3). In 1992, the index increased sharply to over 16000 tons but declined thereafter to 3300 tons in 1994 and 5400 tons in 1995 . The 1994 estimate was likely biased downward due to a largermesh liner in the codend of the trawl that year (NAFO, 1996). Standard errors of the mean catch per mile showed increased variation with the higher estimates. A comparison between the 1995 biomass estimate (5 413 tons) and the provisional catch (about 33000 tons) illustrates that the research catches provide a relative index and not a measure of absolute biomass. 

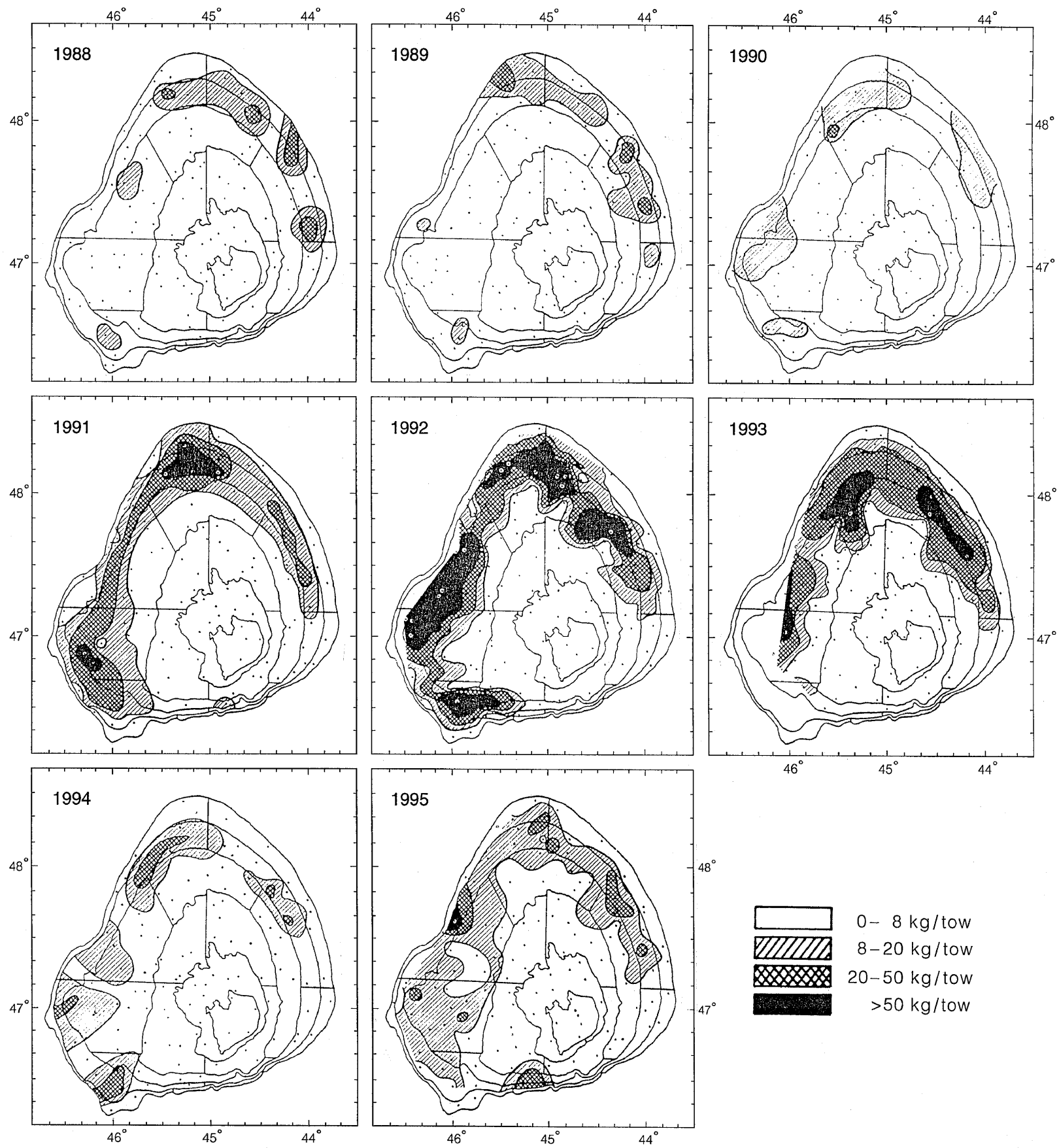

Fig. 12. Shrimp density on Flemish Cap as determined from EU-Spain research trawl surveys, 1988-95. (A. Vazquez, Inst. Inv. Mar., Vigo, Spain, pers. comm.).

Shrimp biomass was concentrated in depths of 250-550 m (Sainza, MS 1995), similar to the depth range of the commercial fishery. Shrimp also were present in two deeper strata $(>550 \mathrm{~m})$ on the northern edge of the bank, whereas a shallow stratum $(150-180 \mathrm{~m})$ near the centre of the Cap produced shrimp catches only in 1995. The increase in biomass from 1990 to 1992 occurred across all strata in which shrimp were found during the initial surveys. In 1994 and 1995, a greater proportion of the estimated biomass was located in western and southwestern areas, compared to previous 
TABLE 3. Biomass indices for northern shrimp, Pandalus borealis, estimated from EU-Spain research surveys on Flemish Cap, 1988-95.

\begin{tabular}{cccc}
\hline \hline Year & $\begin{array}{c}\text { Biomass index } \\
\text { (tons) }\end{array}$ & $\begin{array}{c}\text { Mean catch } \\
\mathrm{kg} / \mathrm{mile}\end{array}$ & $\begin{array}{c}\text { Standard } \\
\text { error } \\
\mathrm{kg} / \mathrm{mile}\end{array}$ \\
\hline 1988 & 2164 & 1.54 & \pm 0.28 \\
1989 & 1923 & 1.37 & \pm 0.24 \\
1990 & 2139 & 1.53 & \pm 0.21 \\
1991 & 8211 & 5.83 & \pm 0.71 \\
1992 & 16531 & 11.75 & \pm 1.86 \\
1993 & 9256 & 6.57 & \pm 1.04 \\
1994 & 3337 & 2.37 & \pm 0.35 \\
1995 & 5413 & 3.85 & \pm 0.44 \\
\hline
\end{tabular}

years, while shrimp densities in the eastern areas declined substantially, consistent with the westward shift in fishing effort.

Nicolajsen (MS 1995) used commercial fishery data to estimate biomass in 1993 and 1994. Average shrimp density (catch/area swept) within each square of $10^{\circ}$ longitude by $7.5^{\circ}$ latitude was calculated and multiplied by the area of the square. Estimates of biomass summed over all squares decreased from about 24000 tons in 1993 to 14600 tons in 1994.

\section{Length, Sex and Maturity}

Size and sex of shrimp on Flemish Cap have been recorded from the EU-Spain research surveys, beginning in the late-1980s, and from the commercial fishery, beginning in 1993. The standard measurement taken in most cases was the oblique carapace length (CL), measured from the posterior margin of the orbit to the posterodorsal margin of the carapace (Rasmussen, 1953). Sex and maturity (males, transitionals, primiparous and multiparous females) were determined from pleopod characteristics (Rasmussen, 1953) and condition of sternal spines (McCrary, 1971).

Relative abundance-at-length was estimated from research surveys conducted during 1990 to 1995 (Sainza, MS 1995). These data (Fig. 13) traced a prominent size-group of males starting in 1990 which appeared to change sex over a three year period. This component was evident in the population as entirely females in 1994. Other components were traced in subsequent years but showed sex change over one or two years and lower abundance.
Samples from the commercial fishery showed major changes between years in the sizes of shrimp caught. In 1993, catches were composed primarily of large female shrimp whereas, in 1994 and 1995, males became more important (NAFO, 1996). By 1995 , most of the catch in numbers was due to the smallest size group of males (Parsons and Veitch, MS 1995; Siegstad and Hvingel, MS 1995).

Weight ( $W$ in g) carapace-length ( $L$ in $\mathrm{mm}$ ) relationships of the form $W=a L^{b}$ were first derived by Escalante et al. (MS 1990) and Mena (MS 1991) from EU-Spain survey samples using lateral carapace length, measured from the posterior margin of the orbit to the posterolateral margin of the carapace. They calculated relationships separately for males, primiparous females, multiparous females, total females and total for 1988, 1989 and 1990. Coefficients $(a)$ ranged from 0.00032 to 0.00100 and exponents $(b)$ from 2.72 to 3.07. Nicolajsen (MS 1994b) pooled animals of 16 to $29 \mathrm{~mm}$ oblique CL taken from Flemish Cap and the adjacent area in Div. 3L from September 1993 to March 1994, and derived the relationship: $W=0.0004 L^{3.1474}$. Skuladottir (MS 1994) used data from the Icelandic fishery on Flemish Cap in 1994 to produce the relationships: $W=0.000596 L^{3.017}$ for animals without eggs and $W=0.000693 L^{2.99}$ for egg-bearing females (Fig. 14).

\section{Age and Growth}

The first interpretation of age structure from EU-Spain survey results identified three size groups with modes around 18,22 and $25 \mathrm{~mm}$ as ages 1, 2 (males) and 3 (females) (Mena, MS 1991). Parsons and Veitch (MS 1993) reanalysed the 

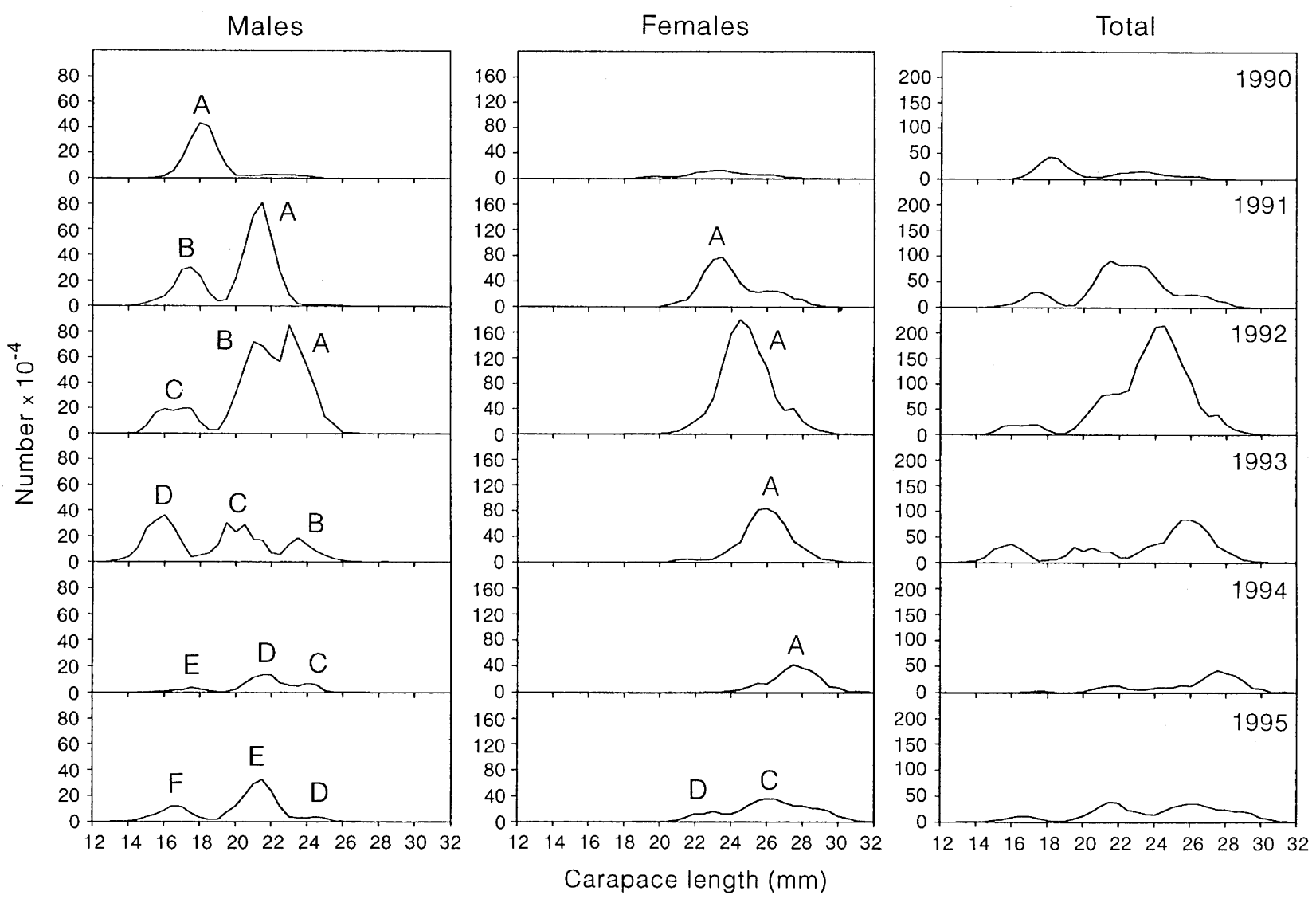

Fig. 13. Time series of research survey length frequency distributions of shrimp on Flemish Cap, 1990-95. A to D denote presumed year-classes (from Sainza, MS 1995).

1988-92 survey data, converting lateral carapace length to oblique carapace length when necessary. They found a size group of males between 16 and $19 \mathrm{~mm}$ carapace length (mode about $18 \mathrm{~mm}$ ) each year with additional male components at approximately $20-21 \mathrm{~mm}$ and $23 \mathrm{~mm}$. Females usually occurred at a mode of 25-26 mm. Size compositions from the 1993 fishery by Canadian vessels were consistent with survey data, but size-specific sex compositions were inconsistent in some years.

Shrimp found in cod stomachs taken from the area during the winters of 1978-84 showed a distinct size group at $7 \mathrm{~mm}$, as well as larger sizes (Lilly, MS 1993). Parsons and Veitch (MS 1993) interpreted these $7 \mathrm{~mm}$ shrimp as males hatched in spring of the previous year. Hence, the first male size group evident in trawl samples $(16-19 \mathrm{~mm})$ was thought to be age 2 and the male components at 20 and $23 \mathrm{~mm}$ ages 3 and 4 , respectively. They further concluded that, if sex inversion occurred at a specific age, primiparous females would be age 5 and multiparous females ages 6+. However, commercial and research survey time series showed variation in the timing of sex change. The data sources further revealed that a strong year-class was produced in the late-1980s, possibly the 1988 yearclass.

Skuladottir and Einarsson (MS 1993) analyzed Icelandic commercial samples from 1993 and found three male cohorts (ages 2, 3 and 4) and three female cohorts (ages 5, 6 and 7). They also analyzed the 1992 EU-Spain survey data which indicated that some of the age 4 animals had already changed sex. Generally, their findings were similar to those of Parsons and Veitch (MS 1993). Skuladottir (MS 1994) also identified the 1988 year-class as strong, and compared length-at-age between samples taken in 1993 and 1994. Nicolajsen (MS 1994c) estimated age composition of shrimp from Faroese catches in 1993 and found that the age 5 group (the 1988 yearclass) was dominant, that females appear as early as age 3 and that all animals are female by age 5 . 

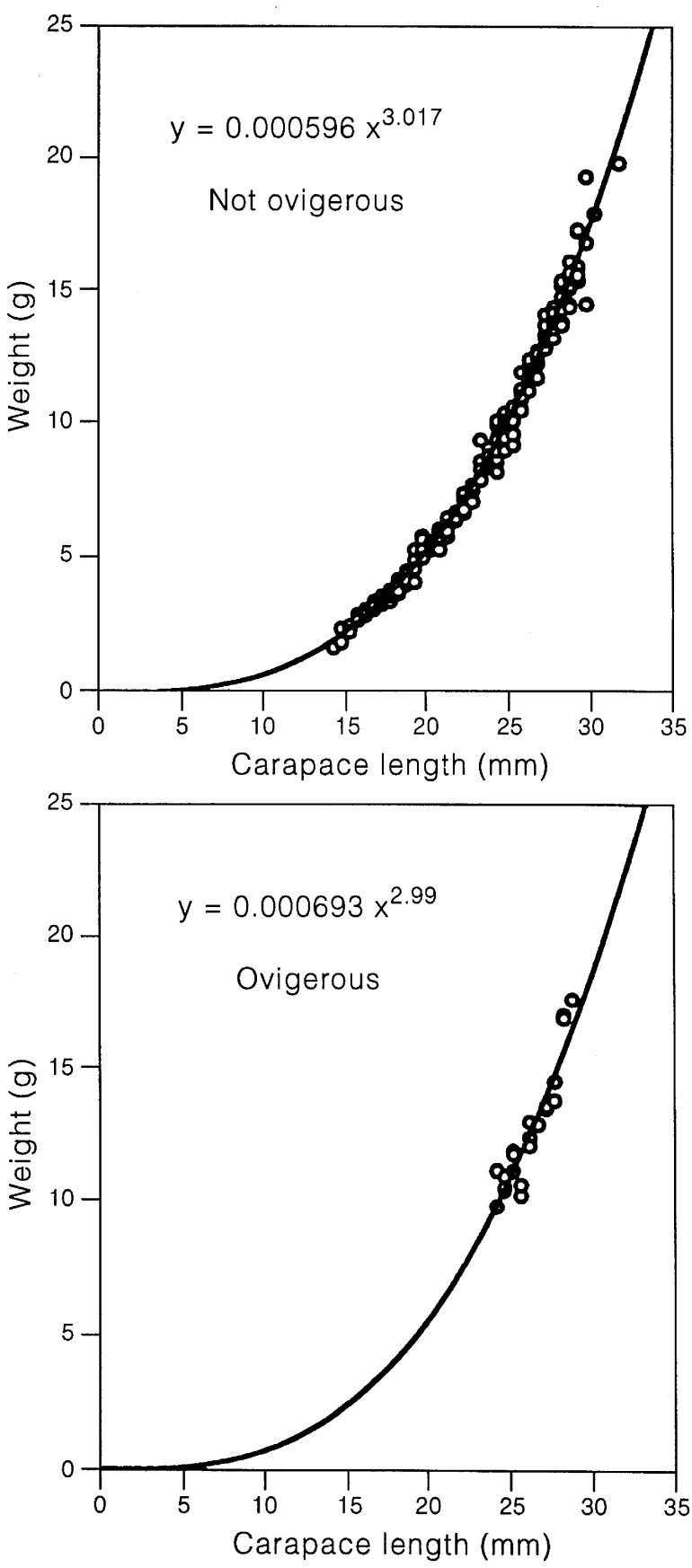

Fig. 14. Weight-length relationships for shrimp caught on Flemish Cap by the Icelandic fishery in 1994 (from Skuladottir, MS 1994).

By 1995 , there was general agreement amongst investigators that three modes of male shrimp, representing ages 2, 3 and 4, usually occur in catches from both the survey and the commercial fishery. There was also a component of females which were assumed to be primarily age $5+$ and can be broken down to age 5 and $6+$ on the basis of the sternal spine characteristics (McCrary, 1971). The ageing is complicated, however, as it has been inferred that some animals in some years change sex between ages 2 and 3 (Sainza, MS 1994) and between ages 3 and 4 (Skuladottir and Einarsson, MS 1993; Nicolajsen, MS 1994c; Parsons and Veitch, MS 1995).

\section{Reproduction}

The fishery for shrimp on Flemish Cap is not restricted by season, catch limit or natural closures due to ice cover, unlike several other fisheries. Thus, the area has produced samples of shrimp which cover the complete reproductive cycle. The proportion of ovigerous females increased during the EU-Spain research survey in the summer of 1990, suggesting that spawning (egg deposition) occurs around late-July to early-August (Mena, MS 1991). Commercial fishery data from Icelandic vessels in 1994 indicated that spawning occurred mainly in August and that all females seemed to spawn each year (Skuladottir, MS 1994). The incidence of ovigerous females in samples taken on Faroese vessels decreased from March through May (Nicolajsen, MS 1994b), indicating that hatching was occurring. Thus, the ovigerous period (egg incubation time) is about 9 months (August to April, inclusive).

Fecundity was estimated from female shrimp taken during the 1990 research survey (Mena, MS 1991). The relationship was $F=1.902 C L^{2.017}$ where $F$ is the number of eggs and $C L$ is the oblique carapace length in $\mathrm{mm}$.

\section{Community Structure}

The Flemish Cap has been the subject of intensive environmental research on both physical and biological processes since the mid-1970s (see overview by Lilly, 1987). The area traditionally has supported a commercial fishery dominated by Atlantic cod (Gadus morhua) and redfish (Sebastes sp.) (Templeman, 1976). Capelin (Mallotus villosus) and sand lance (Ammodytes dubius), the dominant shelfdwelling pelagic fish on the adjacent Grand Bank, are generally thought to be rare visitors (Lilly, 1987). However, Frank et al. (1996) observed that capelin occurred in abundance during several years in the early-1990s. Table 2 lists several of the species and species groups encountered in the fishery as by-catch. 
Wells and Baird (MS 1989) listed 75 fish species from the Flemish Cap over a depth range of 130-730 meters, noting 21 as predominant. Skates (Raja sp.), wolffish (Anarhichas sp.), redfish (Sebastes sp.), Atlantic cod, American plaice and witch flounder were common throughout the depth range, while Greenland halibut, longfin hake, grenadiers (Macrouridae), lanternfish (Myctophidae) and eelpouts (Lycodes sp.) occurred primarily in depths greater than $260 \mathrm{~m}$. Paz and Casas (MS 1995) analyzed data from bottom trawl surveys (1989-94) to define zonation and associations of fish fauna on the Cap. They defined three depth zones: $<300$ $\mathrm{m}$ where Atlantic cod and redfish (Sebastes marinus) dominated the biomass; 301-600 m dominated by redfish (Sebastes mentella); and $>600 \mathrm{~m}$ where Greenland halibut comprised most of the biomass but where $S$. mentella and species of grenadier were also abundant. Vazquez (MS 1995), analyzing the same data set as Paz and Casas (MS 1995) for biomass and abundance of various groundfish species of commercial interest, also produced biomass estimates for squid (Illex sp.) and northern shrimp. It appears, however, that most of the work on community structure and faunal assemblages in the Flemish Cap area has focused on demersal fish species.

\section{Predators}

Northern shrimp are preyed upon by many of the demersal fish which are reported in bottomtrawl catches on Flemish Cap. Rodriguez-Marin et al. (MS 1994) surveyed the feeding habits of 14 species of fish in summer 1993 and constructed an index of relative importance for prey species using data on frequency of occurrence and percentages of prey by number and weight. They found northern shrimp to be of high importance for thorny skate (Raja radiata); of moderate importance for longfin hake (Urophycis chesteri), Greenland halibut (Reinhardtius hippoglossoides), roughhead grenadier (Macrourus berglax), and spotted wolffish (Anarhichas minor); and of low importance for beaked redfish (S. mentella), cod (G. morhua), Atlantic wolffish (Anarhichas lupus) and Arctic eelpout (Lycodes reticulatus). Northern shrimp were either absent from or occurred rarely in the stomachs of other redfish (S. marinus and S. fasciatus), common grenadier (Nezumia bairdi), American plaice (Hippoglossoides platessoides) and witch flounder (Glyptocephalus cynoglossus). Other studies agree that northern shrimp are of low importance for redfish (Konstantinov et al., 1985; Paz et al., MS 1989; Albikovskaya and Gerasimova, 1993) and of very low importance for American plaice (Konstantinov et al., 1985; Paz et al., MS 1989).

The majority of feeding studies on the Flemish Cap have focused on cod because of its large individual size, high biomass and importance to the fishery. Northern shrimp were found to be prey of cod during exploratory surveys by the Soviet Union in 1959 and 1960 (Popova, 1962), and continued to be noted as prey in Soviet and Russian studies between 1964 and 1988 (Turuk, 1968; Konstantinov et al., 1985; Albikovskaya and Gerasimova, 1993). Shrimp also were found to be prey for cod in Canadian studies during 1978-84 (Lilly, MS 1993), and in Spanish studies during 1988-93 (Cardenas et al., MS 1993; Paz et al., 1993; Casas and Paz, MS 1994). However, most reports emphasize predation by cod on commercially important fish (e.g. redfish and cod) (Lilly, 1987). In studies that included shrimp, they ranked as the third or fourth most important prey of cod, after hyperiid amphipods, juvenile redfish and sometimes lanternfish (Myctophidae). Studies further revealed that shrimp are eaten by a broad size range of cod (Konstantinov et al., 1985; Lilly, MS 1993) and that predation occurs over much of Flemish Cap, particularly in an arc from the southwest to the north and east (Lilly, MS 1993). Predation on shrimp occurs throughout the year. However, Turuk (1968) stated that the feeding by cod on shrimp is reduced to a minimum during summer and autumn, and Albikovskaya and Gerasimova (1993) reported that predation by redfish on shrimp "increased in autumn and winter when the biomass of other major food items was at a low level".

It is difficult to determine if the intensity of predation by cod on shrimp has varied over time because studies have differed in many ways, including time of year, spatial coverage, sampling protocol, and method of reporting. Lilly (MS 1993) found that the quantity of shrimp in cod stomachs was low in the late-1970s, increased in the early-1980s, and declined by 1984. Changes in the number of shrimp at length in the cod stomachs were consistent with the hypothesis that a pulse of shrimp recruitment occurred in 1979 and 1980. However, the increase in shrimp biomass on Flemish Cap in the early1990s was not reflected in an increase in the intensity of predation by cod. The partial fullness index of shrimp in cod stomachs and the contribution of shrimp to the cod diet on a percentage weight basis were much lower in 1989-92 (Casas and Paz, MS 
1994) than in 1980-83 (Lilly, MS 1993). This may be related to the seasonality of the studies; the observations in 1989-92 were in summer whereas those in 1980-83 were in winter.

\section{General Discussion}

Recent oceanographic, meteorological and ice conditions of the Northwest Atlantic have been dominated by three anomalous periods; the early1970s, mid-1980s and early-1990s. During these periods, strong positive winter North Atlantic Oscillation (NAO) index anomalies were associated with colder than normal air temperatures over the Northwest Atlantic, increased ice cover and colder and fresher oceanographic conditions over most of the continental shelf in Atlantic Canada. The temperature anomalies on the Flemish Cap show very similar patterns and are highly correlated with severe meteorological and ice conditions experienced over the same time intervals in the Northwest Atlantic. It is not yet clear how the oceanography of the Flemish Cap relates to changes in shrimp abundance and biology. Strong year-classes appear sporadically and their abundance might depend on environmental conditions (e.g. maintenance of the gyre at critical periods) as well as on the abundance of the spawning biomass. Size and age at sex inversion might be related to temperature but are likely to be density dependent, as well. The role of the environment in determining shrimp abundance and affecting life history characteristics requires a substantial research commitment.

It is unknown whether northern shrimp on Flemish Cap constitute a separate population. The anticyclonic gyre provides a mechanism for larval retention similar to that implied for ichthyoplankton. Shrimp larvae are generally believed to remain within the first $50 \mathrm{~m}$ of the water column for two or three months. Information on recirculation and resident times suggest that larvae could be retained over the Cap until they reach the juvenile, settling stage. However, larval drift from areas of the northeast Newfoundland and Labrador Shelf and retention on the Cap also are possible. A clearer understanding of recruitment processes is critical for reliable evaluation of stock conditions.

Age and growth of shrimp have been studied extensively and there is consensus among researchers that the 1988 year-class was strong. Age interpretation is complicated, however, as a result of variation in the age at sex reversal, both within and between cohorts. Generally, the biological characteristics defining growth and maturation of shrimp on Flemish Cap resemble those of warmer water populations during the early life history stages (first year or two) and colder water populations, thereafter. This is consistent with influences of the Gulf Stream during the early stages and the effects of the colder water, at greater depths, during the later stages. Average egg production per female in this area appears to be similar to or slightly lower than that observed in some northern populations (e.g. Teigsmark, 1983; Parsons and Tucker, 1986) but lower than in the Gulf of Maine (Haynes and Wigley, 1969).

The fishery has been intensive but no effective regulations to reduce fishing mortality have been introduced, despite uncertainty in stock status and a need for a cautious approach to exploitation. Assessment tools are limited. Commercial catch rates are difficult to interpret as indices of abundance because the fishery has changed spatially over time in order to maximize catch rates of smaller male shrimp, as female abundance declined. Although the EU-Spain groundfish surveys on Flemish Cap provide a valuable time-series of information on shrimp, directed shrimp surveys also are required to assess the fishable stock and estimate the recruitment.

By-catch in the fishery has been reduced through the mandatory use of sorting grates. These devices are effective at eliminating large fish from the catches but small fish of several species can still be captured by the trawl. Therefore, if strong yearclasses of fish are produced from time to time, bycatch will be problematic as long as individuals are small enough to pass through the bar spacings of the grates. It is difficult to assess the efficacy of the sorting grates in reducing the by-catch of small redfish. As sorting devices were introduced and bar spacings were decreased, the fish (possibly representing a strong year-class or two) grew in size and decreased in numbers through mortality.

Predators of shrimp on Flemish Cap are numerous. However, there have been no attempts made at estimating the number or weight of shrimp consumed by predators and the relationship between shrimp abundance and predator abundance has not been determined. In addition, there has been no investigation of the degree to which the feeding on 
shrimp by various predators might be influenced by the abundance and availability of other prey such as small redfish and hyperiid amphipods. Lilly (MS 1993) concluded that stomach content data from Atlantic cod might provide circumstantial evidence for annual changes in shrimp abundance, but cautioned that there had been no study conducted on Flemish Cap of the relationship between the quantity of shrimp in cod stomachs and the abundance of shrimp. He offered that the number of shrimp at length in cod stomachs might provide greater insights into changes in shrimp abundance.

\section{Acknowledgments}

We appreciate the efforts of T. Amaratunga, Assistant Executive Secretary of NAFO, A. Nicolajsen of Fiskorannsoknarstovan, Faroe Islands, and an anonymous reviewer for contributing to and improving the manuscript.

\section{References}

ALBIKOVSKAYA, L. K., and O. V. GERASIMOVA. 1993. Food and feeding patterns of cod (Gadus morhua L.) and beaked redfish (Sebastes mentella Travin) on Flemish Cap. NAFO Sci Coun. Studies, 19: 31-39.

ALLEN, J. A. 1959. On the biology of Pandalus borealis Kroyer, with reference to a population off the Northumberland coast. J. Mar. Biol. Assoc. U. K., 38: 189-220.

ANDERSON, J. T. 1984. Early life history of redfish (Sebastes sp.) on Flemish Cap. Can. J. Fish. Aquat. Sci., 41 (7): 1106-1116.

APOLlONIO, S., and E. E. DUNTON. MS 1969. The northern shrimp Pandalus borealis, in the Gulf of Maine. Dept. Sea and Shore Fish. MS, Augusta, Maine, $82 \mathrm{p}$.

BARR, L. 1970. Diel vertical migration of Pandalus borealis in Kachemak Bay, Alaska. J. Fish. Res. Board Can., 27: 669-676.

BERENBOIM, B. I. 1981. Feeding of northern shrimp in Barents Sea. Biol. Morya, 5: 28-32. (Transl.)

BERKELEY, A. A. 1930. The post-embryonic development of the common Pandalids of British Columbia. Contr. Can. Biol. Fish., N.S., 6(6): 79-163.

BUTLER, T. H. 1971. A review of the biology of the pink shrimp (Pandalus borealis). In: Proceedings - Conference on the Canadian Shrimp Fishery, St. John, N.B., Oct. 27-29, 1970. Can. Fish. Rep., No. 17: 17-24.

1980. Shrimps of the Pacific coast of Canada. Can. Bull. Fish. Aquat. Sci., 202: 280 p.

CASAS, J. M., and J. PAZ. MS 1994. Diet of Flemish Cap cod with particular reference to predation on redfish: 1988-93. NAFO SCR Doc., No. 24, Serial
No. N2390, 21 p.

COLBOURNE, E. MS 1993. Oceanographic conditions on the Flemish Cap during the summer of 1993, with comparisons to the long-term average. NAFO SCR Doc., No. 107, Serial No. N2300, 36 p.

MS 1996. Oceanographic conditions on the Flemish Cap during the summer of 1996, with comparisons to the previous year and the 1961-1990 average. NAFO SCR Doc., No. 87, Ser. No. N2770, $16 \mathrm{p}$.

COLBOURNE, E. B., and D. R. SENCIALL. 1996. Temperature, salinity and sigma-t along the standard Flemish Cap transect. Can. Tech. Rep. Hydrogr. Ocean Sci., 172: v + 222 p.

DE CARDENAS, E., E. RODRIGUEZ-MARIN, F. SABORIDO, M. CARNEIRO, and J. GILL. MS 1993. Preliminary results of European cod tagging programme in NAFO Division 3M (second year). NAFO SCR Doc., No.16, Serial No. N2193, 29 p.

ESCALANTE, J. L., J. VAZQUEZ, and I. MENA. MS 1990. Northern prawn (Pandalus borealis) stock in Flemish Cap. NAFO SCR Doc., No. 47, Serial No. N1764, 6 p.

FRANK, K. T., J. SIMON, and J. E. CARSCADDEN. 1996. Recent excursions of capelin (Mallotus villosus) to the Scotian Shelf and Flemish Cap during anomalous hydrographic conditions. Can. J. Fish. Aquat. Sci., 53: 1473-1486.

HAYNES, E. B., and A. L. WIGLEY. 1969. Biology of the northern shrimp Pandalus borealis in the Gulf of Maine. Trans. Amer. Fish. Soc., 98: 60-76.

HOPKINS, C. C. E., J. R. SARGENT, and E. M. NILSSEN. 1993. Total lipid content, and lipid and fatty acid composition of the deepwater prawn Pandalus borealis from Balsfjord, northern Norway: growth and feeding relationships. Mar. Ecol. Prog. Ser., 96: 217-228.

HORSTED, Sv. Aa., and E. SMIDT. 1956. The deep sea prawn (Pandalus borealis) in Greenland waters. Medd. Dan. Fisk. - Havunders., 1(11): 118 p.

ITO, H. 1976. Some findings concerning Pandalus borealis Kroyer originating in the Sea of Japan. Bull. Jap. Sea Reg. Fish. Res. Lab., No. 27: 75-89.

KITANO, Y., and T. YORITA. 1978. Pink shrimp stock off west Kamchatka Peninsula and its exploitation. Bull. Hakkaido Reg. Fish. Res. Lab., 43: 1-20.

KONSTANTINOV, K. G., T. N. TURUK, and N. A. PLEKHANOVA. 1985. Food links of some fishes and invertebrates on Flemish Cap. NAFO Sci. Coun. Studies, 8: 39-48.

KUDLO, B. P., V. A. BOROVKOV, and N. G. SAPRONETSKAYA. 1984. Water circulation patterns on the Flemish Cap from observations in 1977-82. NAFO Sci. Coun. Studies, 7: 27-37.

KUDLO, B. P., and V. A. BOROVKOV. 1977. Hydrological regime of the Labrador current and reproduction of commercial fishes. Syezd Sovetskikh Okeanologov, Tezisy Dokladov, Moskva vyp. ii: 133-134. 
KUDLO, B. P., and V. D. BOYTSOV. 1979. The effect of water dynamics on year-class strength of cod on Flemish Cap. ICNAF Sel. Pap., 5: 7-9.

KULKA, D. W. MS 1996. Discarding of cod (Gadus morhua) in the northern cod and northern shrimp directed fisheries from 1980-1994. NAFO SCR Doc., No. 46, Serial No. N2721, 12 p.

KULKA, D. W., and J. R. FIRTH. 1987. Observer program training manual - Newfoundland Region. Can. Tech. Rep. Fish. Aquat. Sci., 1355 (Revised): 197 p.

KULKA, D. W., and D. POWER. MS 1996. By-catch in the NAFO Division 3M shrimp fishery, 1993-1995. NAFO SCR Doc., No. 64, Serial No. N2740, 15 p.

KULKA, D. W., J. S. WROBLEWSKI, and S. NARYANAN. 1995. Inter-annual patterns in the winter distribution and recent changes and movements of northern Atlantic cod (Gadus morhua Linnaeus, 1758) on the Newfoundland-Labrador shelf. ICES J. Mar. Sci., 52: 889-902.

LILLY, G. R. 1987. Synopsis of research related to recruitment of Atlantic cod (Gadus morhua) and Atlantic redfishes (Sebastes sp.) on Flemish Cap. NAFO Sci. Coun. Studies, 11: 109-122.

LILLY, G. R. MS 1993. Sizes, distribution and relative abundance of northern shrimp (Pandalus borealis) on Flemish Cap (Division 3M) in 1978-1984, as inferred from analysis of cod stomach contents. NAFO SCR Doc., No. 105, Serial No. N2298, 12 p.

LODER, J. W., C. K. ROSS, and P. C. SMITH. 1988. A space and time-scale characterization of the circulation and mixing over submarine banks, with application to the northwestern Atlantic continental shelf. Can. J. Fish. Aquat. Sci., 45: 1860-1885.

LONGHURST, A. R. 1970. Crustacean resources. In: The fish resources of the oceans. J. A. Gulland, [ed.]. FAO Fish. Tech. Pap., No. 97: 252-305.

McCRARY, J. A. 1971. Sternal spines as a characteristic for differentiating between females of some pandalidae. J. Fish. Res. Board. Can., 28: 98-100.

MENA, I. MS 1991. Northern prawn shrimp (Pandalus borealis) length distribution and fecundity in Flemish Cap. NAFO SCR Doc., No. 29, Serial No. N1909, $7 \mathrm{p}$.

MS 1992. Northern prawn shrimp (Pandalus borealis) stock in Flemish Cap. NAFO SCR Doc., No. 66, Serial No. N2120, 3 p.

NAFO. MS 1993. Management measures for 3M and 3LNO shrimp. NAFO FC Doc., No. 10, Serial No. N2327, 1 p.

MS 1994a. Provisional nominal catches in the Northwest Atlantic. NAFO SCS Doc., No. 24, Serial No. N2487, 44 p.

MS 1994b. Decisions by the Fisheries Commission on the conservation and enforcement measures in the Regulatory Area. NAFO FC Doc., No. 8, Serial No. N2471, 1 p.

1995a. NAFO Stat. Bull., Vol. 42. Fishery Statistics for 1992 .

1995b. NAFO Sci. Coun. Rep., 1994, 176 p.
MS 1995. Management of shrimp fishery. NAFO FC Doc., No. 21, Serial No. N2645, 2 p.

1996. NAFO Sci. Coun. Rep., 1995, 172 p.

NICOLAJSEN, A. MS 1993. Assessment of the shrimp stock on Flemish Cap (Division 3M) for 1993. NAFO SCR Doc., No. 103, Serial No. N2296, 7 p.

MS 1994a. Assessment of the northern shrimp stock on Flemish Cap (Division 3M). NAFO SCR Doc., No. 78, Serial No. N2457, 7 p.

MS 1994b. Growth and reproduction in northern shrimp on Flemish Cap (Division 3M) and the Nose of the Bank (Division 3L) in September 1993May 1994. NAFO SCR Doc., No.77, Serial No. $\mathrm{N} 2456,15 \mathrm{p}$.

MS 1994c. Age structure of northern shrimp in Division 3M in September-November 1993 and Division 3L in March 1994. NAFO SCR Doc., No. 76, Serial No. N2455, 9 p.

MS 1995. Biomass estimate of the northern shrimp stock on Flemish Cap (Division 3M) for 1993 and 1994. NAFO SCR Doc., No. 105, Serial No. $\mathrm{N} 2628,17 \mathrm{p}$.

PARSONS, D. G. MS 1982. Biological characteristics of northern shrimp (Pandalus borealis Kroyer) in areas off Labrador. M.Sc. Thesis, Department of Biology, Memorial University of Newfoundland, $123 \mathrm{p}$.

MS 1994. Preliminary assessment of shrimp (Pandalus borealis) in Division 3M (Flemish Cap). NAFO SCR Doc., No. 82, Serial No. N2461, 10 p.

MS 1995. Assessment of shrimp (Pandalus borealis) in Division 3M (Flemish Cap) - 1995. NAFO SCR Doc., No. 106, Serial No. N2629, 8 p.

MS 1996. Assessment of shrimp (Pandalus borealis) in Division 3M (Flemish Cap). NAFO SCR Doc., No. 102, Serial No. N2785, 9 p.

PARSONS, D. G., and G. E. TUCKER. 1986. Fecundity of northern shrimp, Pandalus borealis, (Crustacea, Decapoda) in areas of the northwest Atlantic. Fish. Bull., 84(3): 549-558.

PARSONS, D. G., and P. J. VEITCH. MS 1993. Age and growth of northern shrimp (Pandalus borealis) on Flemish Cap (NAFO Division 3M). NAFO SCR Doc., No. 112, Serial No. N2306, 11 p.

MS 1994. The Canadian fishery for northern shrimp (Pandalus borealis) on Flemish Cap (NAFO Division 3M). NAFO SCR Doc., No. 83, Serial No. N2462, 9 p.

MS 1995. The Canadian fishery for northern shrimp (Pandalus borealis) on Flemish Cap (NAFO Division 3M), 1993 to 1995. NAFO SCR Doc., No. 103, Serial No. N2626, 10 p.

PARSONS, D. G., P. J. VEITCH, and E. M. SEWARD. MS 1993. The Canadian fishery for northern shrimp (Pandalus borealis) on Flemish Cap (NAFO Division 3M), 1993. NAFO SCR Doc., No. 111, Serial No. N2305, $10 \mathrm{p}$.

PAZ, J., and J. M. CASAS. MS 1995. Zonation and associations of dominant fish fauna in Flemish Cap. 
NAFO SCR Doc., No. 45, Serial No. N2556, 12 p. PAZ, J., J. M. CASAS, and G. PEREZ-GÁNDARAS. 1993. The feeding of cod (Gadus morhua) on Flemish Cap, 1989-90. NAFO Sci. Coun. Studies, 19: 41-50.

PAZ CANALEJO, J., F. J. VAZQUEZ ALVAREZ, A. FERNANDEZ ARROYO, and J. M. CASAS SANCHEZ. MS 1989. The feeding of American plaice (Hippoglossoides platessoides), redfish (Sebastes marinus) and cod (Gadus morhua) in the Flemish Cap during July 1988. NAFO SCR Doc., No. 45, Serial No. N1622, 15 p.

POPOVA, O. A. 1962. Some data on the feeding of cod in the Newfoundland area of the Northwest Atlantic. In: Soviet Fisheries Investigations in the Northwest Atlantic, Y. Y. Marti (ed.). VNIRO-PINRO, Moskva. p. 228-248. (Transl. from Russian for U.S. Dep. Int. Nat. Sci. Found., Washington, D.C., by Israel Prog. Sci. Transl. 1963.)

RASMUSSEN, B. 1953. On the geographical variation of growth and sexual development of the deep sea prawn (Pandalus borealis, Kroyer). Fiskeridir. Skr. Havunders., 10(3): 1-160.

1965. The fishery for deep sea prawn in Norway. In: Proceedings of the Symposium on Crustacea, p. 1437-1441. Symposium Series 2, Marine Biological Association of India.

RODRIGUEZ-MARIN, E., A. PUNZON, J. PAZ, and I. OLASO. MS 1994. Feeding of most abundant fish species in Flemish Cap in summer 1993. NAFO SCR Doc., No. 35, Serial No. N2403, 33 p.

ROSS, C. K. 1981. Drift of satellite-tracked buoys on the Flemish Cap, 1970-80. NAFO Sci. Coun. Studies, 1: 47-50.

SABORIDO-REY, F. MS 1995. Age and growth of redfish in Flemish Cap (Div. 3M). NAFO SCR Doc., No. 31, Serial No. N2540, 16 p.

SAINZA, C. MS 1993a. Northern shrimp (Pandalus borealis) stock on Flemish Cap. NAFO SCR Doc., No. 22, Serial No. N2199, 5 p.

MS 1993b. Northern shrimp (Pandalus borealis) stock on Flemish Cap in June-July 1993. NAFO SCR Doc., No. 104, Serial No. N2297, 8 p.

MS 1994. Northern shrimp (Pandalus borealis) on Flemish Cap in July 1994. NAFO SCR Doc., No. 81, Serial No. N2460, 6 p.

MS 1995. Northern shrimp (Pandalus borealis) on Flemish Cap in July 1995. NAFO SCR Doc., No. 100, Serial No. N2622, 6 p.

SHUMWAY, S. E., H. C. PERKINS, D. F. SCHICK, and A. P. STICKNEY. 1985. Synopsis of biological data on the pink shrimp, Pandalus borealis, Kroyer, 1883. NOAA Tech. Rep., NMFS 30, FAO Fish. Synop., 144: $57 \mathrm{p}$.

SIEGSTAD, H. MS 1993. The Greenland fishery for northern shrimp (Pandalus borealis) on Flemish Cap, May-August 1993. NAFO SCR Doc., No. 110, Serial No. N2304, 5 p.

MS 1994. The Greenland fishery for northern shrimp (Pandalus borealis) on Flemish Cap, 1993 and 1994. NAFO SCR Doc., No. 86, Serial No. $\mathrm{N} 2466,13 \mathrm{p}$.

SIEGSTAD, H., and C. HVINGEL. MS 1995. The Greenland fishery for northern shrimp (Pandalus borealis) on Flemish Cap, NAFO Division 3M, in 1994 and 1995. NAFO SCR Doc., No. 101, Serial No. N2624, $9 \mathrm{p}$.

SKULADOTTIR, U., and S. EINARSSON. MS 1993. The Icelandic shrimp (Pandalus borealis) fishery at the Flemish Cap in 1993, with a preliminary analysis of age structure. NAFO SCR Doc., No. 101, Serial No. N2294, 9 p.

SKULADOTTIR, U. MS 1994. The Icelandic shrimp (Pandalus borealis) fishery at the Flemish Cap in 1994. NAFO SCR Doc., No. 85, Serial No. N2465, $10 \mathrm{p}$.

SQUIRES, H. J. 1970. Decapod Crustacea of Newfoundland, Labrador and the Canadian eastern Arctic. Fish. Res. Board Can. Manuscr. Rep. Ser. (Biol.), 810: $212 \mathrm{p}$.

1968. Relation of temperature to growth and self-propagation in Pandalus borealis from Newfoundland. FAO Fish. Rep., 57: 243-250.

1992. Recognition of Pandalus eous Makarov, 1935 , as a Pacific species not a variety of the Atlantic Pandalus borealis Kroyer, 1838 (Decapoda, Caridea). Crustaceana, 63(3): 257-262.

TEMPLEMAN, W. 1976. Biological and oceanographic background of Flemish Cap as an area for research on the reasons for year-class success and failure in cod and redfish. ICNAF Res. Bull., 12: 91-117.

TIEGSMARK, G. 1983. Populations of the deep-sea shrimp (Pandalus borealis Kroyer) in the Barents Sea. Fiskeridir. Skr. Havunders., 17: 377-430.

TURUK, T. N. 1968. Seasonal changes of cod feeding in the Labrador and Newfoundland areas in 1964-66. Trudy-PINRO, 23: 370-382. (Transl. from Russian by Fish. Res. Board Can. Transl. Ser. 1937, 1971).

VAZQUEZ, A. MS 1989. Results from bottom-trawl survey of Flemish Cap in July 1988. NAFO SCR Doc., No. 60, Serial No. N1640, 15 p.

MS 1995. Results from bottom-trawl survey of Flemish Cap in July 1994. NAFO SCR Doc., No. 26, Serial No. N2535, 33 p.

WELLS, R., and J. W. BAIRD. MS 1989. Fish populations on the Flemish Cap. NAFO SCR Doc., No. 90, Serial No. N1664, 40 p.

WIENBERG, R. 1981. On the food and feeding habits of Pandalus borealis Kroyer 1838. Arch. Fischereiwiss. 31: 123-137. 